\section{㓞性都市主义中的生态设计 \\ DESIGNING ECOLOGIES FOR RESILIENT URBANISMS}

\section{OSA的研究与实践}

都市主义与建筑研究小组 (OSA ) ${ }^{\mathbb{1}}$ 是比利时鲁汶大学基于实践的 都市主义学术研究团队, 其旨在解决那些亟需深刻转变的当代问题。 当今世界所面临的严峻生态和社会危机已引起全人类的强烈共鸣。OSA 将 (基于设计的) 研究与实践并重, 以研究指导实践, 以实践检验研 究; 并进行了长期的合作性探索。通过实地考察、工作坊、密集的国 际暑期课程、咨询、教职工及博士生研究、实践项目等方式, OSA对 社会和空间环境长期而深人的探索使得相关知识不断丰富和扩充，并 在立足全球的同时，发掘了地方性知识。最为重要的是，OSA倡导的 都市主义不仅基于对严峻的全球性危机的充分认知, 同时还格外强调
布鲁诺·德 ·缪德尔

比利时鲁汶大学工程科学学院建筑系都市主义专业教授

凯利·香农

比利时鲁汶大学工程科学学院建筑系都市主义专业副教授

摘要

本文对比利时鲁汶大学基于实践的都市主义 研究团队一一都市主义与建筑研究小组近期的一 系列研究进行了介绍。随着当代社会、生态、空 间不平等问题愈加突出, 都市主义与建筑研究小 组试图通过设计来塑造富有活力的生态环境, 营 建韧性城市。他们的研究与实践项目遍布全球, 主要从三个角度探讨了场地问题: 水都市主义; 森林都市主义; 塑造拥有抗性的全新社会生态。 文章的第一部分结合案例阐述了都市主义与建筑 研究小组的设计理念; 第二部分以概要的形式对4 个近期正在进行中的设计研究项目予以介绍。

\section{关键词}

都市主义与建筑研究小组; 实践型设计研究; 水 都市主义；森林都市主义；社会生态；抗性
Bruno De MEULDER

Professor of Urbanism, Department of Architecture, Faculty of Engineering Sciences, KU Leuven

\section{Kelly SHANNON}

Associate Professor of Urbanism, Department of Architecture, Faculty of Engineering Sciences, KU Leuven

clo KU Leuven, Faculty of Engineering Sciences, Department of Architecture, asteelpark Arenberg I, 300I Heverlee, Belgium

kelly.shannon@kuleuven.be

\section{ABSTRACT}

This article encapsulates the recent work of OSA, a practice-based urbanism situated in an academic environment (KU Leuven, Belgium). In the contemporary era of increased social, ecological, and spatial injustices, OSA's work attempts to create resilient urbanisms through designing robust ecologies. Its worldwide sites of research and interventions are primarily addressed through three themes: water urbanisms, forest urbanisms, and creating new social ecologies as resistance. The first part of the article provides an overview of the ambitions of OSA with a number of examples. The second component consists of four excerpts of recent and on-going design research.

\section{KEY WORDS}

Onderzoeksgroep Stedenbouw en Architectuur; Practice-Based Design Research; Water

Urbanisms; Forest Urbanisms; Social Ecologies; Resistance 
1) OSA (Research Group Urbanism and Architecturel consists of professors Viviana d'Auria, Bruno De Meulder, and Kelly Meulder, and Kelly there is one postdoc, Eliana Rosa De Queiroz Barbosa, and approximately 30 doctoral students. The research group The research group teaches in and support the undergraduate Bachelor of Engineering Sciences: Architecture and two post-graduate educational programs: a one-year Master of Human Settlements (MaHSl and two-year Master af Urbansim and Strategic Planning (MaUSP) (see http:// www.mahsmausp.be/l.
要因地制宜地制定解决方案。其有意规避当代近乎霸权的主流城市实 践一一这些实践只不过是在市场驱动下的全球主义新自由浪潮中随波 逐流的项目, 并未解决当今时代最急迫的社会和生态挑战。OSA致力于 在不断演变的城市发展相关议题和都市主义之间开展能够激发二者互 动的新兴实践。概言之, OSA在应对那些需要作出深刻转变的问题时, 其实践是基于研究的、干预导向型的、立足于实际背景的、带有批判 性的，且面向未来规划。

作为一个研究导向型都市主义实践团队, OSA认为都市主义是跨 学科的, 也具有多重衡量指标, 其融合了从生态学、气候变化研究、 农学、林业、水文学到人类学与社会学、法学与政治学、城市研究与 规划等众多学科知识。OSA从历史发展纵深和当代横向这两种比较视角 来解读场地，借助测绘分析进行问题诊断，通过跨地区尺度的、能够 反映场地信息的制图学进行预测, 并制定切实的设计方案。OSA所倡导 的根植于特定环境背景的都市主义以各种项目、计划、规划和政策的 形式对场地的现状和未来产生影响。OSA以具体实践作为当代城市转型 的触媒，从而引导向可持续空间的转变。这些实践除了会促成具有吸 引人的设计外, 还有助于各种利益相关者之间的沟通协商。

OSA的基础研究和实践相辅相成。实地调查及研究与设计通过系 统性迭代, 形成了一个彼此互为预设条件和检验反馈的过程（同时也 会不断衍生出新的研究) 。这一过程随着研究和实践的进展而持续强 化, 并扩大了当地利益相关者群体, 拓展了学科内部和跨学科的交 流。这种迭代过程没有终点，是一个不断激发并持续推进的过程一 这亦是一个启迪认识的过程, 提出了启发性的设想, 并取得了丰硕的

\section{OSA Research and Intervention}

OSA (Onderzoeksgroep Stedenbouw en Architectuur, Research group Urbanism and Architecture) ${ }^{\circledR}$, a practice-based urbanism situated in the academic environment of KU Leuven, Belgium, deliberately addresses pressing contemporary issues necessitating profound transitions. Consequently, the dramatic ecological and social crisis the world is facing resonates strongly. OSA iterates between (design) research and intervention. It is collaborative and persistent. Intense immersion within social and spatial contexts for substantial time allows for the accumulation of knowledge (through fieldwork, studios, intensive international summer schools, consultancies, staff and $\mathrm{PhD}$ research, projects, etc.). It engages global and unfolds local expertise. Most importantly, OSA propagates an urbanism that while well aware of acute global challenges, simultaneously, intentionally and radically resists generic solutions. It deliberately distances itself from the contemporary body of mainstream conventional, almost hegemonic, urban projects that do little more than surf on the neo-liberal waves of market-driven globalism and leave the most pressing social and ecological challenges of our time unaddressed. OSA situates itself in alternative emerging practices that unfold new interactions between evolving urban development issues and urbanism. OSA is 1) research-based; 2) intervention-oriented; 3) contextual; 4) critical; and 5) futureprojected (addressing issues that require profound transition).

As a research-oriented practice of urbanism, OSA considers urbanism as trans-disciplinary and trans-scalar. It integrates knowledge from a wide-range of disciplines - from ecology, climate change studies, agronomy, forestry, hydrology to anthropology and sociology, law and political science, urban studies and planning. OSA reads territories from diachronic and synchronic perspectives, diagnoses through interpretative mapping, and prognoses through projective cartography across territorial scales, and conceives concrete interventions. It is an urbanism that, while engaging with specific contexts, impacts the immediate and far-away through a wide-range of forms of projects, programs, plans, and policies. OSA uses concrete, tangible entrance points to contemporary urban transition agendas in order to trigger sustainable spatial transformations. Tangible entrance points facilitate, besides appealing designs, communication and negotiation with various stakeholders.

OSA's fundamental research and practice feed one another. Fieldwork and research systematically iterate with design, which becomes a process that alternates proposition and feedback (including new rounds of research). The process intensifies with each step and amplifies outreach to local stakeholders as 
实践成果。在这种模式下, OSA提出了许多基于特定环境和问题的项 目、方案、规划和政策主张, 涉及社会和政府的多个层面。没有任何 一个项目可以解决所有问题。只有大量的项目、规划和行动共同配合 并不断扩散其影响, 才可能引发转变。因此, 对于整个过程的精心统 筹是不可或缺的。

OSA既不提倡普适性解决方案, 也不提倡最佳实践一一实际上, OSA从根本上无法苟同这些观念。在过去 20 多年中, OSA发展了一种 方法论一一其立足于场地特定环境背景, 运用一般性途径 (例如, 实 地调查、设计作为研究、研究结合生产等) 并借用已有见解和方法 （例如, 联合国粮农组织的农业生态区划方法）, 以不断探索地方独 特性。这套方法论有助于深人了解当地的传统、特征及身份认同、固 有优势和能力以及场地资产, 并推导出因地制宜的应对方法。显而易 见, 对于具体环境的响应将有助于项目、计划、规划或政策被人们积 极接受, 尽管这一点很少被承认，也鲜有实践涉及。OSA认为这是人们 理解和接受 (继而传播) 干预措施的必要条件。在这种转变过程中, 不同形式的政治和行政组织的经验都变为了宝贵的、不断累积的知识 而被分享和传播。最后, 需要在结合其他学科知识的基础上创新性地 运用规划工具, 以组织和管理从规划到实施的演变过程一包括开始 转变土地开发模式 (例如, 从分区规划到综合开发)、转让开发权、 汇集供需以达到质变等——并在这一过程中接受检验和传播。

\section{2 经由统筹设计的、旨在应对洪水问题的新城市类型}

早在10年前, OSA就开始关注 “水都市主义” 相关议题。纵观都市 主义的发展历程, 其本质上是以水系统为基础的。城市体系和水系之 间的相互作用非常关键, 但都市主义或水资源管理领域却很少对之有 明确阐释。OSA有意在其研究和实践中强调这种基本相互作用, 这其中 既有古老的本土系统的传承, 也受到一种借助自然力量的新方法的启 迪（正如软性工程和城市设计的结合）。水都市主义旨在解决城市中 日益严峻的水环境挑战, 构建景观基础设施, 并重新调整工程化和自 然的过程。气候变化 (包括干旱、洪水、海平面上升和海水人侵等) 预测结果、雨洪和流域管理的新压力, 以及对于生态的关注催生了 OSA 的一系列设计研究和项目实践, 它们共同印证了水和都市主义之间的 相互依存关系。OSA在水都市主义方面的工作主要集中在亚洲（包括中 国、越南、印度尼西亚、印度、斯里兰卡和孟加拉国）, 以及比利时 和美国的多个地区。 well as exchange within and across disciplines. The iterative process does not have an end goal, but ambitions to catalyze and continuously fuel a itself. It initiates awareness, creates eyeopening propositions, and results in project definitions. OSA's iterative and persistent processes leads to a multitude of contextspecific and issue-tailored projects, programs, plans, and policy propositions, which operate at different levels of society and government. There is never a single project that changes everything. Transition requires a multitude of projects, plans, and initiatives that in a chain leading to other projects. Orchestration is required and consequently integral part of the endeavor.

OSA has neither one-size-fits-all outcomes nor bestpractices. Indeed, it radically resists such notions. Instead, over the past two decades, OSA has developed a methodology a contextually immersed approach that, while using general techniques (as, for example, fieldwork, research by design, and co-production procedures), insights and methods (for example, the agro-ecological zoning method derived from the Food and Agriculture Organization of the United Nations), continuously seeks local specificity. The methodology works to deeply understand local traditions, characters and identity, endogenous strengths and capacities, and site assets. Such a base subsequently conditions its tailored-responsive approach. It is evident (but seldom recognized and acted upon) that tangible context responsiveness is critical for the positive reception of any project, program, plan or policy. OSA assumes it a necessary condition for conception as well as reception (transmission and dissemination). The experiences during such transition processes with different forms of political and administrative organizations are shared as invaluable, cumulative knowledge. Finally, there is the innovative use of planning tools, in combination with other disciplinary knowledge, to organize transitions from plan to implementation — including initiating changes in (attitudes towards) land-use (from zoning to mixed development, for example), transfer of development rights, pooling of demands and offers to achieve critical mass - and get tested and disseminated through the process.

\section{Choreographed Flooding and New Urban Typologies}

OSA has a long-term interest in what it coined a decade ago "water urbanisms." Historically, urbanism was intrinsically anchored on water structures. The interplay between urban and water structures remains essential but is seldom articulated, neither in urbanism nor in water resources management. OSA deliberately underscores this elementary interplay in its research and projects that are informed by age-old indigenous systems 
温珮君在她的博士研究《生产性都市主义: 中国台湾嘉南平原 生产景观与聚落相互作用中的水资源冲突》（2009-2014）中, 探索 了该区域在农业生产率大幅下降、人口减少, 以及气候变化态势严峻 的背景下, 与水相关的景观 (特别是稻田和潮间带水产养殖场) 的转 变。该研究主要关注两个地区: 曾文溪河湾地区（这里曾经人口密度 较高、土地管理单位较小, 且社会联系紧密, 现如今正经历着彻底重 构) 和布袋沿海地区。重建台湾北部的桃园农田陂塘蓄水防洪系统是 曾文溪景观项目的首要策略性干预措施。此外, 设计重新划定土地管 理单位 (每个水利设施的服务范围为 $150 \mathrm{hm}^{2}$ ) 以提高生产力, 同时恢 复了嘉南平原紧凑的村落形式。布袋地区主要面临着地面沉降和洪水 问题, 通过对该地区进行结构调整, 设置新的雨水滞留池、曝气泻湖 和新的 (水产) 养殖区域而加以解决, 项目中大面积的废弃盐碱地被 多元文化和光伏农业所取代, 同时, 通过地形一堤坝系统保护村庄和 关键基础设施免受洪水侵袭（图1）。

OSA还在越南开展了大量工作。对于正处于自由市场经济转型期的 越南来说, 需要依据其现实背景来设定发展的规模、范围和速度。大 规模的农村人口涌人城市一一主要包括越南两个城市化程度较高的三 角洲和部分位于低地海岸的城市——这一问题由于极端的气候变化而 变得愈加复杂。OSA通过与联合国人居署为越南北部城市荣颈以及芹苴 重新编制城市总体规划, 为这两个城市创建了切实可行的强大的水系 和植被框架, 以缓解极端气候变化所带来的影响。2014 2017年,

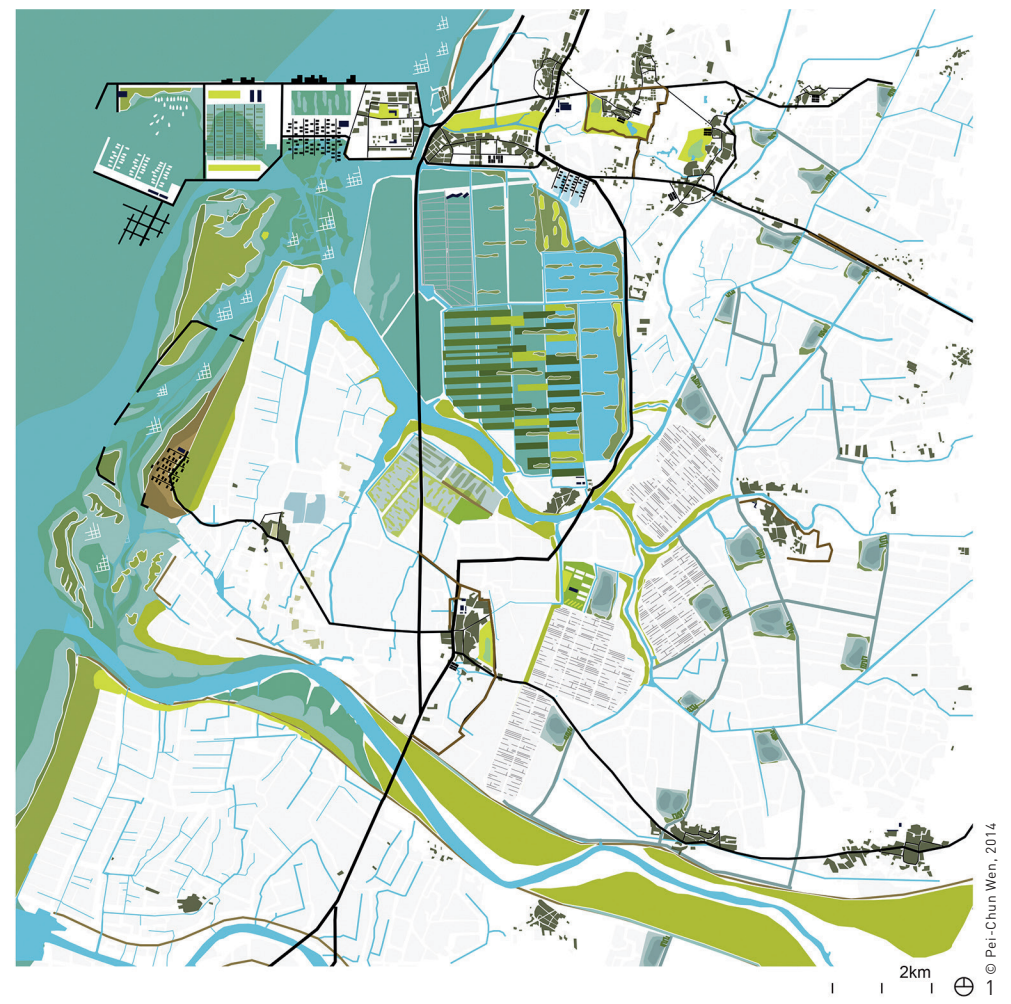

as well as new ways to work with the forces of nature vis-avis a combination of soft-engineering and urban design. Water urbanism addresses the growing challenges of water in the city, infrastructural landscapes, and the readjusting of both engineered and natural processes. The predicted consequences of climate change (drought, floods, sea level rise and saline intrusion), new pressures of stormwater and basin management, and ecological concerns have led to design research and projects that create rich interdependencies of water and urbanism. OSA's work in water urbanisms has been primarily focused in Asia (including China, Vietnam, Indonesia, India, Sri Lanka and Bangladesh), various regions of Belgium and the USA.

Pei-Chun Wen developed her doctoral research, Productive Urbanism: Water Conflicts in the Interplay of Production Landscapes and Settlements in the Chia-Nan Plain, Taiwan (20092014), to explore the transformation of water-based landscapes (particularly rice farming and inter-tidal aquaculture) in the region's context of plummeting agricultural productivity, declining population, and the challenges of climate change trends. She focused on two case studies: the Tsengwen River bend area where the once high population density, small land units, and intensive social interconnections are undergoing radical restructuring, and the coastal Budai region. Reinterpretation of the Tao-Yuan farm pond system (in northern Taiwan) of water storage and flood control was the primary strategic intervention for the Tsengwen River landscape. As well, land management units were redefined (150 hectares per water conservancy unit) to increase productivity while simultaneously restoring the compact village form of the Chia-Nan Plain. The Budai region's primary challenges of land subsidence and flooding were addressed by restructuring the territory to include new rainwater retention basins, aerated lagoons, and new (aqua)culture production - poly-culture and photovoltaic farming, replacing vast areas of abandoned salt pans. A landform-dyke system protects villages and critical infrastructure from flooding (Fig. 1).

OSA has as well worked extensively in Vietnam. The nation's scale, scope and speed of development in light of its transitional free-market economics demands context-specific response. Extensive rural to urban migration, primarily to its two urbanized deltas and cities strung along its low-lying coast, is complicated by extreme climate changes. OSA worked in the northern city of Vinh with UN-Habitat and Cantho in the Mekong Delta to develop new urban masterplans, which both created strong water and vegetal frames to mitigate extreme climate changes. From 2014 to 2017, OSA led a team in collaboration with the Southern Institute of Strategic Planning (SISP) to revise the Mekong Delta Regional Plan 2030, Vision to 2050, a commission by the 
OSA通过与南方战略规划研究所 (SISP) 合作, 接受了越南建设部的 委托, 为涺公河三角洲制定2030 2050年间的区域发展愿景规划。原规 划试图在该地区采用常见的基础设施、工业和城市发展模式; 与之相 反, OSA从根本上对该地区的内在特征和场地环境中的自然动态变化 加以重新组织。渞公河三角洲最具特色的就是当地无处不在的水, 该 地区各个尺度的土地利用都构建在水系结构的基础之上。为了突显当 地农业的重要性 (包括三角洲的内在价值和越南国家粮食安全的必要 性）, 新规划对古老的 “水力文明” 进行了重新梳理, 并对 “城乡结 合带” 的分布进行了重新组织。三角洲当前的景观形态 (包括大小、 形式和坡度等所有你能想得到的方方面面）都是由历史长河中土地与 水系的相互作用共同塑造的。新的区域规划力求实现最优的水陆相互 作用, 并将涺公河三角洲的未来发展建立在当地复杂的水域环境上: 景观变成了基础设施; 阻力变为了资源; 旁路改造为了与主路平行的 林荫道, 以修复后工业时代过度依赖机械化和集中化产业布局（而后 衰败) 的伤疤。该规划不仅为当代创造了一个意在与动态变化的自然 (尤其是当地无处不在的水) 重新融合的基础设施, 创建了一种内涵 丰富的、能够自我更新的三角洲海岸生态, 还提出了三种新的聚落类 型和相应的布局密度, 以应对气候变化的影响（图2）。
Ministry of Construction. In opposition to the existing Mekong Delta Regional Plan that superimposed generic infrastructural, industrial, and urban development models on the territory, the revision radically re-engaged with the inherent qualities of the territory and the context-embedded dynamics what nature imposes on the territory. The indigenous quality of the Mekong Delta is its omnipresent water that defines and structures the territory across all scales. Renewed logics of the age-old "hydraulic civilization" and organized dispersal of "desakota" are part-and-parcel of the contemporary plan, which sought to strengthen agricultural importance in light of the delta's intrinsic value and Vietnam's need of national food security. The delta's landscape is the historical result of a layered and highly choreographed interplay between land and water in all the volumes, measures, and gradients one can imagine. The main operation of the revised Mekong Delta Regional Plan was to define the optimum water-land interplays and graft the further development of the Mekong Delta on its sophisticated water register. Landscape becomes infrastructure, resistance becomes source, bypasses act as parallel avenues to other futures than the over-mechanized and centralized (and run-down) territory of the postindustrial era. The plan not only created an infrastructure for the 21st century which would purposefully reengage with the dynamics of nature (that here in the Mekong Delta is mainly the omnipresent water) and the notion of a thickened, self-renewing deltaic coast ecology, but also developed three new settlement typologies and densities that respond to climatic variance (Fig. 2).

Tuan Pham Anh's doctorate, Water Urbanism in Hanoi, Vietnam: An Investigation into Possible Interplays of Infrastructure,
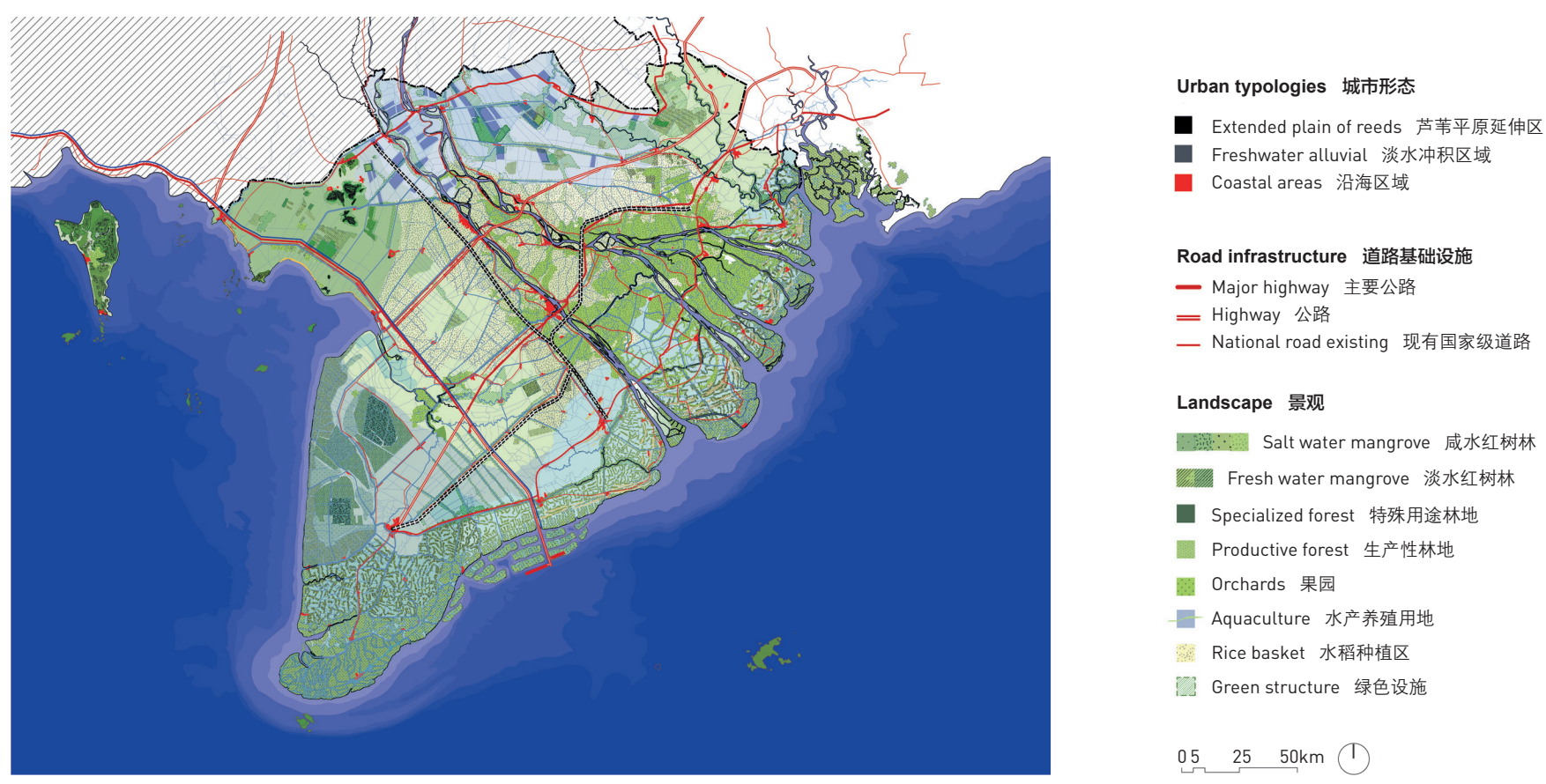

2. 渭公河三角洲地区愿景规 划（2030-2050)。基础 划 $(2030-2050)$ 。基础 设施建设和区域发展在重 视景观脆弱性的同时, 也 积极化气候变化的挑战为 机遇。涺公河三角洲被优 化为一种生产性景观, 借 助最先进的填海技术在越 南东海地区营建一个新兴 世界。

2. Mekong Delta Region Plan 2030 Vision to 2050. Infrastructure and development are realigned to take advantage of climate change while respecting the vulnerabilities of the landscape. The delta is optimized as a productive landscape and a new state-of-the-art polytechnic reclamation is conceived on the East Sea. 
3. 越南河内地区红河上的 多用途堤防系统。图 中所示分别为的 究团队的方案 (A) 究团队的方案 (A) 韩国研究团队的方案 (B) 、越南研究团队 的方案 (C), 以及OSA 提出的方案 (D)。新 的方案提出了一种通过 拓宽河流空间来适应河 流动态变化的方法, 洪 流动态变化的方法, 䜤 泛平原应在保持现有面

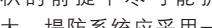
大, 堤防系统应采用一 种分层系统以对不同的 临界水位进行调控。

3. A Hybrid Red River Dyke, Hanoi, Vietnam. Japanese proposal (A): Jouth Korean proposal (B); Vietnamese proposal (C); New proposal of the design research (D). The new proposal suggests an approach that works with the dynamics of water by giving space to the rivers. Flood plains should be kep and expanded as large as possible. The dike system should be developed as a hierarchical system, which can deal with different critical water levels.
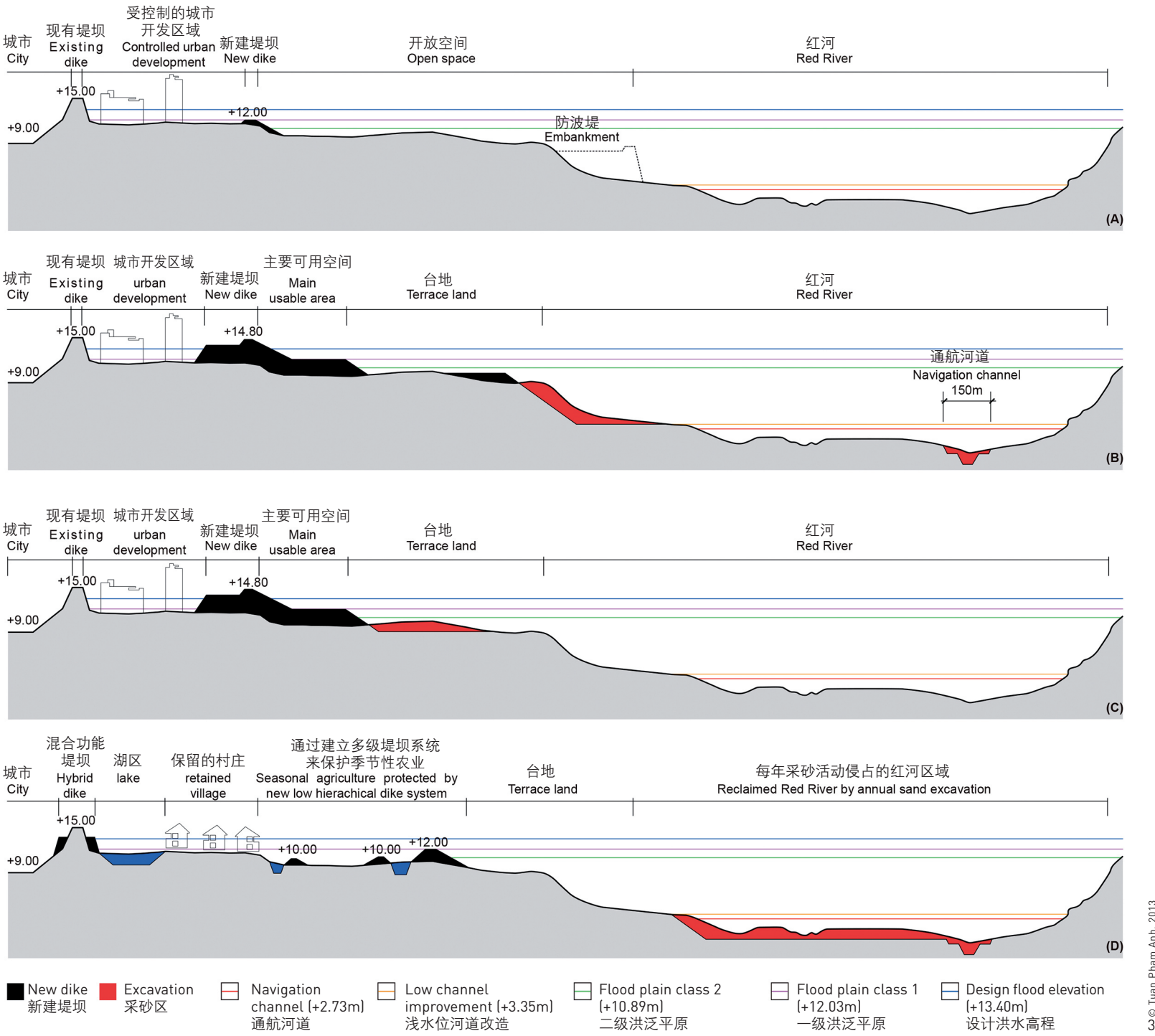

图范安的博士研究《越南河内的水都市主义: 对城市堤防系统 的基础设施、都市主义与景观之间可能的相互作用之调查》（20092013 ) 关注雄伟的红河及其支流。这一关乎城市存亡的生命线在 20 世 纪的城市发展中被渐渐忽视。在过去的 20 年间, 非正规定居点在高度 工程化的堤防系统的周边聚集。由来自越南、日本和韩国的研究团队 新近提出的防洪方案皆主张修建硬质工程和大幅加高堤坝。图范安的 这项研究聚焦于河内的两个案例：红河安所河段和天河（红河支流） 楚松河段。二者皆为贫困地区, 它们分散的城市形态和大规模的农业 耕地受到来自河内的洪水和城市化（或郊区化）曼延的威胁。项目提 出一种多用途综合堤防系统, 以适应河内多变的水文环境, 保护有价 值的农业用地, 顺应基础设施建设规则, 并指导未来的城市化进程 (图3)。
Urbanisms, and Landscape of the City's Dike System (2009-2013), focused on the mighty Red River and its tributaries. During the 20th century, this water system transformed from the lifeline of the city to its backside. Over the past two decades, there has been an explosion of unauthorized settlement beyond its highly engineered dyke system. Recent flood control proposals by Vietnamese, Japanese, and South Korean research and development groups relied heavily on hard-engineering and the dramatic raising of dyke heights. The research focused on two cases in Hanoi: the Red River at Yen So and one of its tributaries, the Day River at Chuc Son. Both areas are relatively poor, and their dispersed urbanism and vast agricultural fields are threatened by increased flooding and spill-over (sub)urbanization from Hanoi. A hybrid dyke system was developed to work with Hanoi's shifting hydrologics, protect valuable agricultural land, accommodate the logics of infrastructural developments, and guide future urbanization (Fig. 3). 
克里斯蒂安 - 诺夫的博士研究《佛兰德斯河段：上游水管理的挑 战和模糊城市的空间建构》（2009-2013）着重于从具体规划到愿景 构想的范式转变, 这种转变不仅转变了 200 年来以拦堵为主的治水观 念、拓宽了河流空间, 还通过重新定义都市主义促进了该地区的未来 发展。在蒂伦豪特 (一个相对紧凑的城镇) 和根克 (一个正经历着分 散城市化的城镇）中, 通过迁移古代 (工业) 遗址、开发城镇中的预 留地, 或者基础设施更新, 来探索与城市结构转变相关的各种场地改 造。佛兰德式的城市景观中的丝状网络被优化为一种针对具体水域环 境的场地开发类型。除了涉及渗透、滞留和储存等方面的典型当代水 管理策略外, 规划同时整合了开放空间、自然地和景观保护区。通过 引人新的与水相关的计划项目, 不仅缝合了碎片化的景观, 也为将其 与地表水体和周边的河流连接成网络创造了契机（图4）。
The doctorate of Christian Nolf, Sections of Flanders: Challenges of Upstream Water Management and the Spatial Structuring of the Nebulous City (2009-2013), focused on a paradigmatic shift from planning to profiling in order to accommodate both the need to make space for water after two centuries of excessive confinement and to requalify urbanism to frame better future development. In Turnhout (a relatively compact town) and Genk (with dispersed urbanism), various sites linked to urban fabric transformations by the reallocation of ancient (industrial) sites, urbanization of reserve land, or recalibration of infrastructures were explored. The filament-like mesh pattern of the Flemish urban landscape was optimized as a site-specific type of development that responds to degrees of wetness. Typical contemporary water management strategies of infiltration, retention, and storage were developed in tandem with an overlay of plans for open space, nature, and landscape protection. The insertion of new water programs was an opportunity not only to requalify the fragmented landscape, but also to connect them into a network, linking surface water bodies to nearest rivers (Fig. 4).
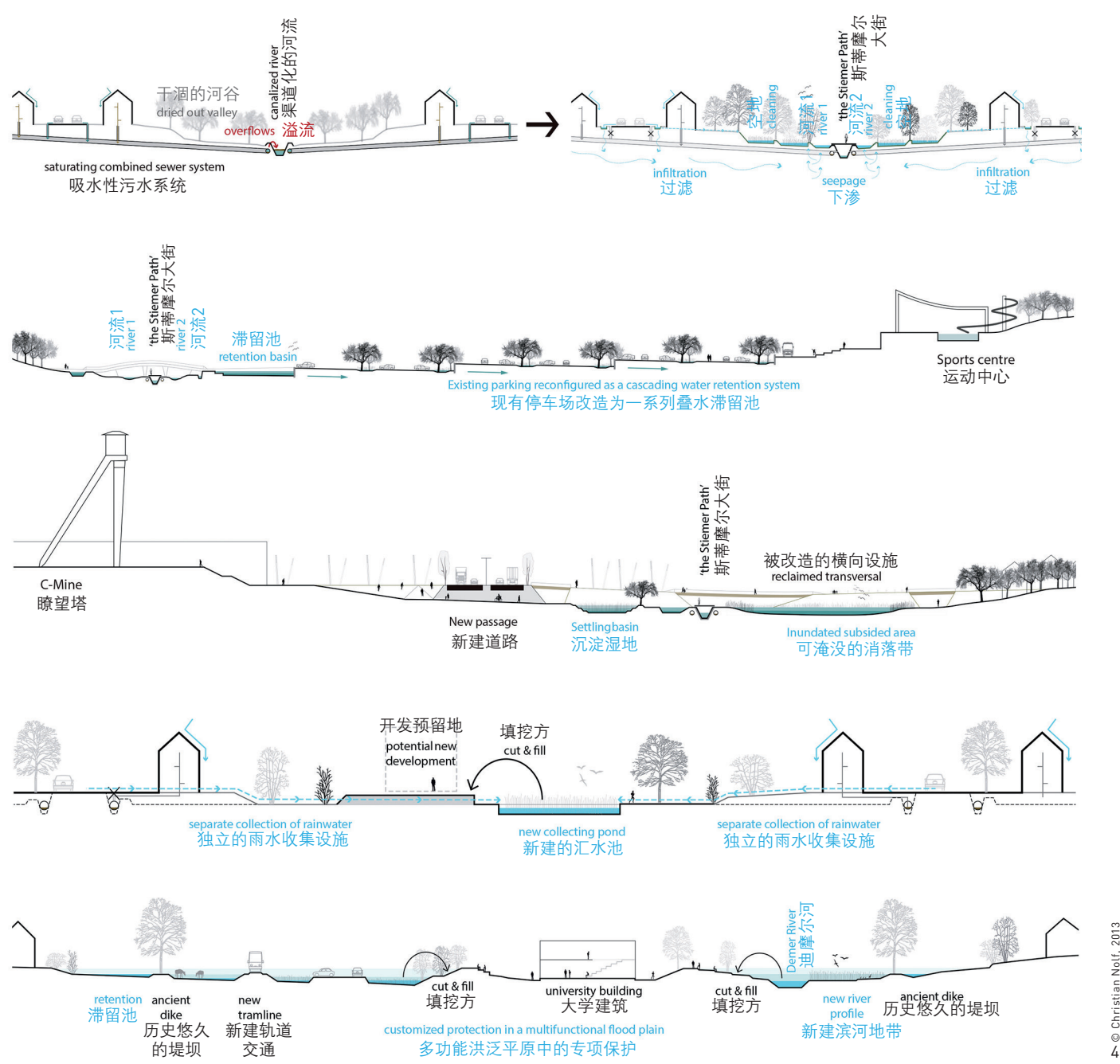

空间需要水: 重建佛兰德 斯河段。水在佛兰德斯市 无处不在, 关键问题在于 如何利用水管理干预措施 （重新）构建城市框架， 进而重塑当地水系。微地 形的重新激活可以增强场 所感, 并孕育出其他的城 市形态。通过联系各个对 各河段的干预，赋予蒂伦 豪特和根克的水域环境以 一系列生态和游息功能。

4. Space needs Water: Reprofiling the Flanders Territory. Water is omnipresent in the dispersed city. The essential issue becomes how water management interventions can be used to simultaneously used to simultaneously
(re)structure urbanity and graft this again on the water structures. The reactivation of microtopography can strengthen the identity of places and stimulate alternate forms of urbanization. Working through sections, a new repertoire of performative and recreational water spaces were investigated for Turnhout and Genk. 


\section{3 森林都市主义}

在设计新的生态系统以提高城市韧性时, 森林显然是不可或缺 的。森林是一种能够自我再生的生态系统, 在这一点上, 它们与城市 的状态截然不同一一城市的（人口、社会文化、经济等方面的）再生 需借助自然、腹地和外部的输人。几个世纪以来，人们对森林进行规 划、开发和维护，相关的管理往往比同时期的城市规划更宽泛、更复 杂一一在法语中，“规划”（ aménagement）一词恰源自于 “森林管 理” (aménagement des fôrets )。纵观城市演变历史, 森林和树木的布 局往往犹如城市的骨架与血肉。一直以来，森林显然成为了城市的图 底, 或被嵌人城市, 或成为城市的补充。森林都市主义借鉴了林业管 理和环境科学的传统，同时不断为各种城市环境创造新的应对途径。

多年来, OSA一直致力于倡导森林都市主义 (通过设计创建一种杂糅环 境），并视之为当代城市基础设施的重要组成部分。今天，树木在城 市中的重要性如何强调都不为过: 其涉及固碳、提升生物多样性、创 造宜人的微气候环境、减少污染, 以及水资源管理等方面, 更对于公 共卫生有着重大意义。

OSA为位于比利时佛兰德斯西南部的勒尔戴尔地区制定了战略规 划。大规模的城市化导致整个勒尔戴尔区域的景观严重碎片化，长期 以来对耕作和生产的迫切需要使得森林面积不断缩减。零散的城市 肌理只与开阔的绿地相互交织, 却鲜与森林融合。对马科地区 (2010 年) 和霍格科特赖克地区（2011年）的规划在地域和城市尺度上进 行。（位于科特赖克郊区的）马科地区尚未开发的开阔地已被政府指 定为植树造林计划的场地 (按照欧洲标准)。该规划并非在肥沃的土 地上植树造林 (避免激怒当地农民), 而是将城市边缘的森林构建为 新的城市发展的空间框架，在此框架中，马科地区将致密化发展，

\section{Forest Urbanisms}

It is evident that in designing new ecologies towards increasing urban resilience, forests are indispensable. Forests operate as self-regenerating ecosystems. In that perspective they are on the opposite side of the spectrum from cities that by definition depend on nature, hinterlands, and external input for regeneration (demographic, socio-cultural, economic, etc.). For centuries, forests were planned, systematically exploited and maintained; often management was more extensive and sophisticated than the town planning of the same period. The French term for planning (aménagement) comes from forest management (aménagement des fôrets). It is not accidental that throughout the history of urbanism, there has been an interweaving of structures of forests and trees with urban armatures and tissues. Forests have traditionally formed the obvious counter-figure of the city, been embedded in the city or complemented the city. Forest urbanisms draw from traditions of forestry management and environmental science, while constantly inventing new techniques for various urban contexts. For years, OSA has worked internationally on the design of the urban forest (by definition a mixed environment) from the premise that it is a critical component of contemporary urban infrastructure. In the contemporary era, the importance of trees in the city cannot be stressed enough: they are essential as carbon sinks, increasing biodiversity, creating desirable microclimates, mitigating pollution, and play an important role in water management. Their importance for public health is paramount.

In Belgium, OSA developed strategic plans for the intermunicipality agency Leiedal in southwest Flanders. Throughout the region, where extensive urbanization results in a highlyfragmented landscape, forests have been unable to resist the longstanding urge of cultivation and production. Scattered urban fabrics intermingle with open and green spaces, but little forest. Designs for Marke (2010) and Hoog-Kortrijk (2011) worked at territorial and urban scales. The remaining open land of Marke, a suburb of Kortrijk, has been designated by the government as the site for an afforestation program (as required by European standards). Instead of developing the forest on rich and fertile land (and hence that farmers would perceive as a provocation), an urban fringe forest was conceived as the new counterpart and spatial frame in which Marke could densify and develop into a more sophisticated residential quarter. The structure of Marke's urban fringe forest simultaneously positions it in the urban region and redefines its urban realm. A "crown forest" is developed between the 30 to $40 \mathrm{~m}$ contours and compensates for a long history of ecological abuse (clay extraction for tile and brick production 
并形成一种更加杂糅的人居环境。同时, 马科的城市边缘森林框架将 其自身置于城市范围之中, 也因此重新定义了城市的边界。在海拔高 度30 40m的区域建立 “冠林带”, 由此弥补长期以来的生态破坏 (历 史上, 当地在此等高线带上开采粘土用于生产砖瓦)。景观轮廓清晰 的冠林带作为勒尔河结构上的补充, 自然地整合了土地; 这种覆盖整 个地区的空间框架, 连同各种山谷森林类型和开放空间, 创造了适用 于不同开发强度和规模的 (混合) 用途的多样化环境。不同类型的马 赛克空间巧妙地嵌于其周边的环境之中, 抑制了城市的蔓延。软质网 络成为连接城市、森林和开放空间的纽带, 包括连通众多东西走向 的难逾屏障 (公路、铁路、勒尔河) 的南北向廊道、一个森林中心环 路, 以及一条平行于公路的景观廊道。丰富的植物类型 (包括果树和 观花树木) 和地表肌理为马科及其周边地区创建了一个新的公共空间 系统, 健全了现有的休闲网络, 并营建了新的生态 (图5)。

霍格科特赖克地区的发展策略以马科地区的发展策略为基础, 并 着眼于开发E 17 公路沿线拥有50多年历史的科特赖克郊区。该地区由 众多单一功能的地块组成 (包括地区医院、大学校园、商业园区、零 售区, 以及一些住宅区), 并依赖私家车通行。重新规划的交通基础 设施包括公共交通、众多步行和 (电动车) 骑行路线, 并大幅减少沥 青路面一一取而代之的是集水元素、成体系的树阵, 以及对现有森林 的大量美化并营建新的森林。霍格科特赖克地区的新规划将现有森林 布局更加紧凑, 并有选择性地创建林间空地。当地通过植树造林确立 了一个空间框架, 其可以使单调乏味的、单一功能的郊区环境在质量 和用途上不断丰富, 更加致密、更加杂糅。其可以为需要隔离的元素 (如高速公路) 创造缓冲, 并 (通过连通和/或共享的方式) 将整个生 态廊道联系起来（图6）。 between these contours). The crown forest, which has a system of "clear-cut" views, complements the Leie River as a structure that naturally orders the territory; it sets an omnipresent spatial frame that is complemented by a wide variety of valley forest types and open spaces that create a diversity of atmospheres - appropriate for a wide range of (mixed) uses of varying intensity and scale. The mosaic of qualitative spaces inscribe themselves subtly within their context, and restructure sprawl. Soft networks function as veins uniting urban, forest, and open spaces, including north-south transversals that cross the multitude of strong east-west barriers (highway, railway, Leie), a central loop within the forest, and a spine paralleling the highway. The rich palette of plant types (including orchards and flowering trees) and ground textures create a new public space system for Marke and its surroundings, complement the existing recreational network, and generate new ecologies (Fig. 5).

The Hoog-Kortrijk strategy builds upon that developed for Marke, while focusing on the development of the half-century old suburban part of Kortrijk along the E17 Highway. The area is characterized by an archipelago of monofunctional elements (regional hospital, college and university campuses, business park, retail, and a few residential enclaves); all is accessed by private car. Vehicular infrastructure is reprogrammed with public transport, ample pedestrian and (e)bike routes, and the radical reduction of asphalt: replaced by water harvesting elements and systematic, multiple lines of trees, and the generous

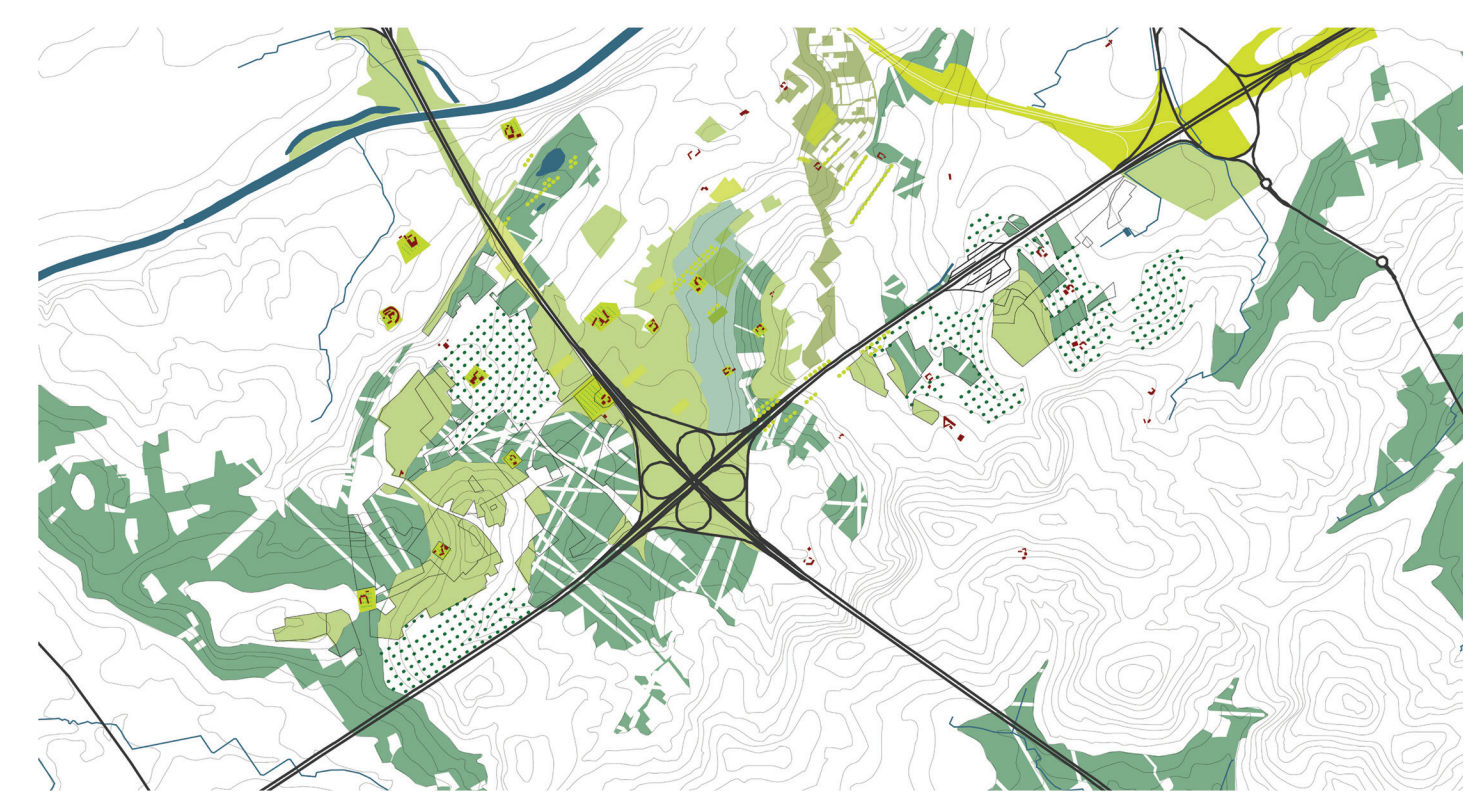

\begin{tabular}{|c|c|}
\hline $\begin{array}{l}\text { Fores } \\
\text { 森林 } /\end{array}$ & $\begin{array}{l}\text { st / Landscape Typologies } \\
\text { |景观用地 }\end{array}$ \\
\hline & $\begin{array}{l}\text { Crown Forest with "Clear Cuts" } \\
\text { 轮廓清晰的冠林带 }\end{array}$ \\
\hline & $\begin{array}{l}\text { Urban Fringe Forests Lauwe-Marke } \\
\text { 罗威-马科城市边缘林带 }\end{array}$ \\
\hline & $\begin{array}{l}\text { Agro-Forests } \\
\text { 农业林地 }\end{array}$ \\
\hline & $\begin{array}{l}\text { Meadow and Grassland Park } \\
\text { 公共草甸与草地 }\end{array}$ \\
\hline & $\begin{array}{l}\text { Village Green } \\
\text { 乡村绿地 }\end{array}$ \\
\hline & $\begin{array}{l}\text { Linear Allee } \\
\text { 线性林荫大道 }\end{array}$ \\
\hline & $\begin{array}{l}\text { West Ring Park } \\
\text { 西环公园 }\end{array}$ \\
\hline
\end{tabular}

Ool $\quad 10.51 \quad 1 \mathrm{kml}$
5. 比利时马科地区的森林 都市主义框架。冠林地 区成为了城市中无处不 在的空间画布, 容纳了 各种山谷森林类型和开 放空间。以这种方式产 生的环境多样性造就了 适宜不同的开发强度和 规模的空间类型。丰富 的植物类型 ( 包括果树 和观花树木) 和地表眀 和观花树木) 和地表肌 理为马科及其周边地区 创建了一个新的公共空 间系统, 补充了现有的 休闲网络, 并营建了新 的生态。

6. 对比利时霍格科特赖克 地区城市中的树木进行 的研究。丰富多样的现 有和新建森林类型包含 众多树大类型和植被种 众多树木类型和植被种 类, 形成了宽阔的城市
生态交错带, 并产生新 的生态和休息环境。

5. Forest Frames for Urbanism, Marke, Belgium. Crown forest sets the omnipresent spatial canvas that accommodates a wide variety of valley forest types and open spaces. The diversity of atmospheres created in this way are appropriate for a wide range of uses of varying intensity and scale. The rich palette types The rich palette types
(including orchards, flowering trees, etc.) and ground textures create a new public space system for Marke and its surroundings, complement the existing recreational network, and generate new ecologies.

6. Trees in the City: HoogKortrijk, Belgium. A rich variety of existing and new forest typologies with a broad palette of tree types and plant species create a wide species create a wide generate new ecologies generate new ecologios
and recreational settings. 


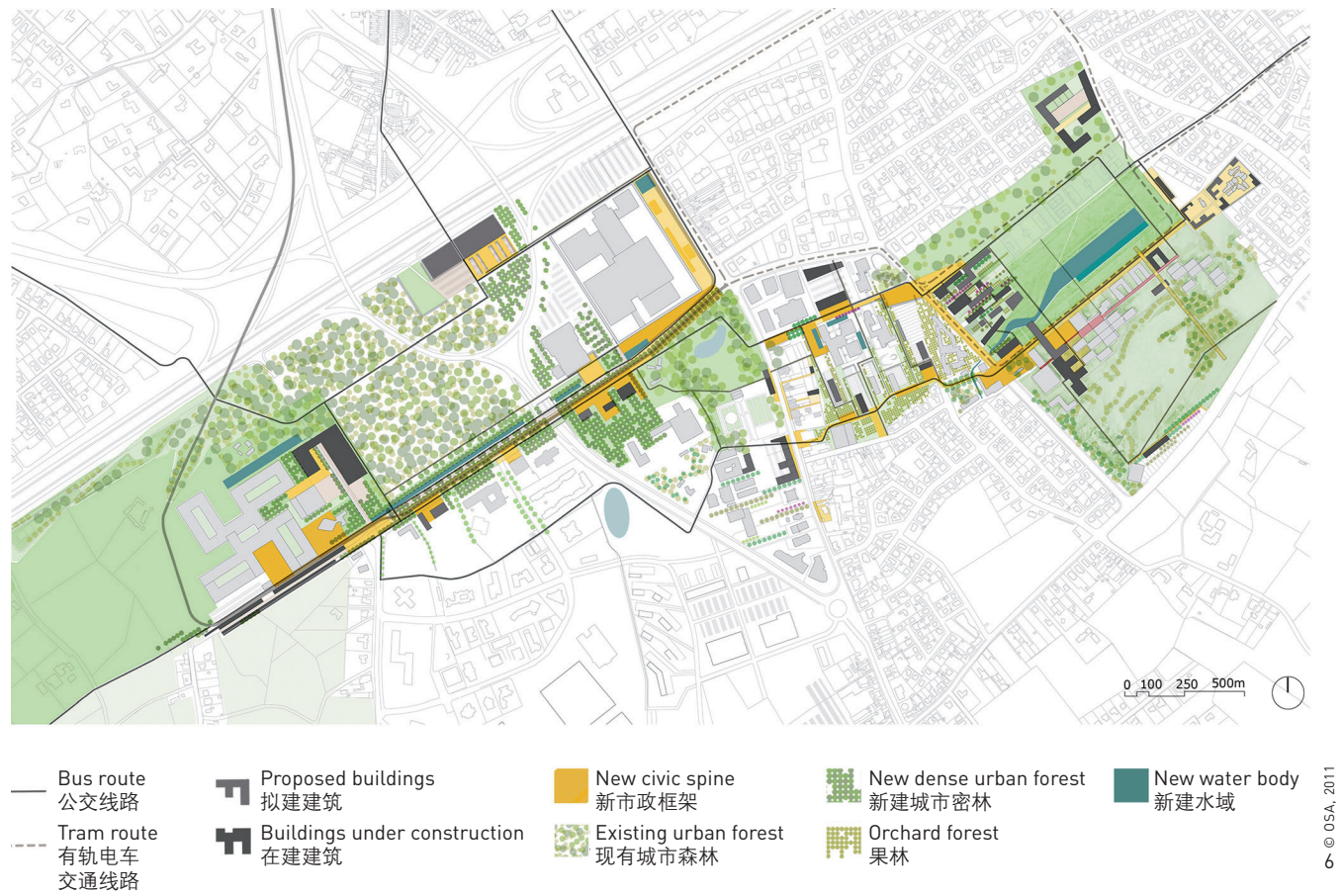

2018年, OSA（与赞比西大学和来自鲁汶大学的研究生合作）重 新审视了莫桑比克中部热带林地的森林都市主义。泰德地区以由灌木 丛及稀薄开阔的林冠林构成的壮观的半干旱草原景观而闻名, 当地居 民（以靠土地维持生计的农民为主）世代在如此景观中生活, 低密度 聚落遍布整个地区。传统上, 当地人会松散地以家族聚居地为中心, 将家安在森林之中。在过去几十年间, 当地的生计和土地利用受到大 规模现代化开发 (包括近来的采矿活动) , 森林砍伐, 以及会导致水 资源短缺、自然过程加速 (如水土流失) 的气候变化的威胁。面对在 林间造屋的当地传统与建造混凝土住宅的当代需求之间无法调和的矛 盾, 方案通过景观都市主义策略批判性地重新诠释并恢复了当地的聚 落建造实践，同时通过采用新技术、探索创新替代方案来应对适应性 挑战，满足当代生活期许。该方案提出 “跳出” 开发误区的概念，在 利用先进技艺的同时，通过聚落和土地利用来重塑景观。该地区的开 敞冠层森林被重建为多功能栖居环境, 成为一个可以嵌人聚落的基本 （景观）结构。这种在广衰草原上重新造林（或使森林布局更加紧 凑）的做法与在泰德的莫阿蒂泽地区和鲁埃尼亚的昌加拉地区的城市 化区域的种植计划完全不同（图7）。

\section{4 拥有抗性的社会生态}

19 20世纪大规模的工业化与城市化进程为全世界带来了前所未有 的环境与社会危机; 通过水都市主义与森林都市主义实践, OSA从环境 embellishment of existing forests and concurrent creation of new ones. New development in Hoog-Kortrijk would be accommodated by densification of the existing and the selective use of clearings within the forest figures. Afforestation of HoogKortrijk defines a spatial frame that allows for a requalification - enriching in quality as well as in use - densification, and hybridization of a monotonous and monofunctional suburban environment. It allows the buffering of what needs separation (such as the highway) and uniting (by relating and or sharing) and interweaves an ecological corridor throughout (Fig. 6).

In 2018, OSA (in collaboration with Universidade Zambeze and post-graduate KU Leuven students) rethought forest urbanism in the tropical woodlands of central Mozambique. The Tete region is identified by its majestic semi-arid savannah landscape with scrublands and thin, open canopy forests. Lowdensity settlements blanket the territory leaving almost no place untouched. Local inhabitants, largely subsistence farmers, have always lived with and within the landscape. Traditionally, settlements loosely aggregate extended-family compounds and are embedded within the forest. Over the past decades, indigenous livelihoods and occupation of the territory are threatened by large modernization projects (including the recent advent of mining), deforestation, and climate change (linked to water scarcity and acceleration of natural processes such as erosion). There is not a balance between the local tradition of compound building amidst trees and contemporary aspirations of modern bungalows in concrete. Landscape urbanism strategies critically reinterpreted and reinvigorated local settlement practices, while simultaneously addressing adaptation challenges and the expectations of contemporary life by appropriating new techniques and exploring innovative alternatives to the statusquo. The work was premised on the notion of "leapfrogging" over the pitfalls of development and adapting settlement and occupation of the land to the qualities of the landscape while making use of the most recent advances in available technologies and technique. The territory's open canopy forest was reconstructed as a polyvalent host environment, in short, as a fundamental (landscape) structure in which settlements could be embedded. Reforestation (or intensification of the forest) on vast plateaus was approached quite differently than the planting schemes that are inserted within various urbanized areas of Moatize, Tete and Changara, Luenha (Fig. 7).

\section{Social Ecologies as Resistance}

Massive industrialization and urbanization during the 19th and 20th centuries plunged the world into unprecedented 


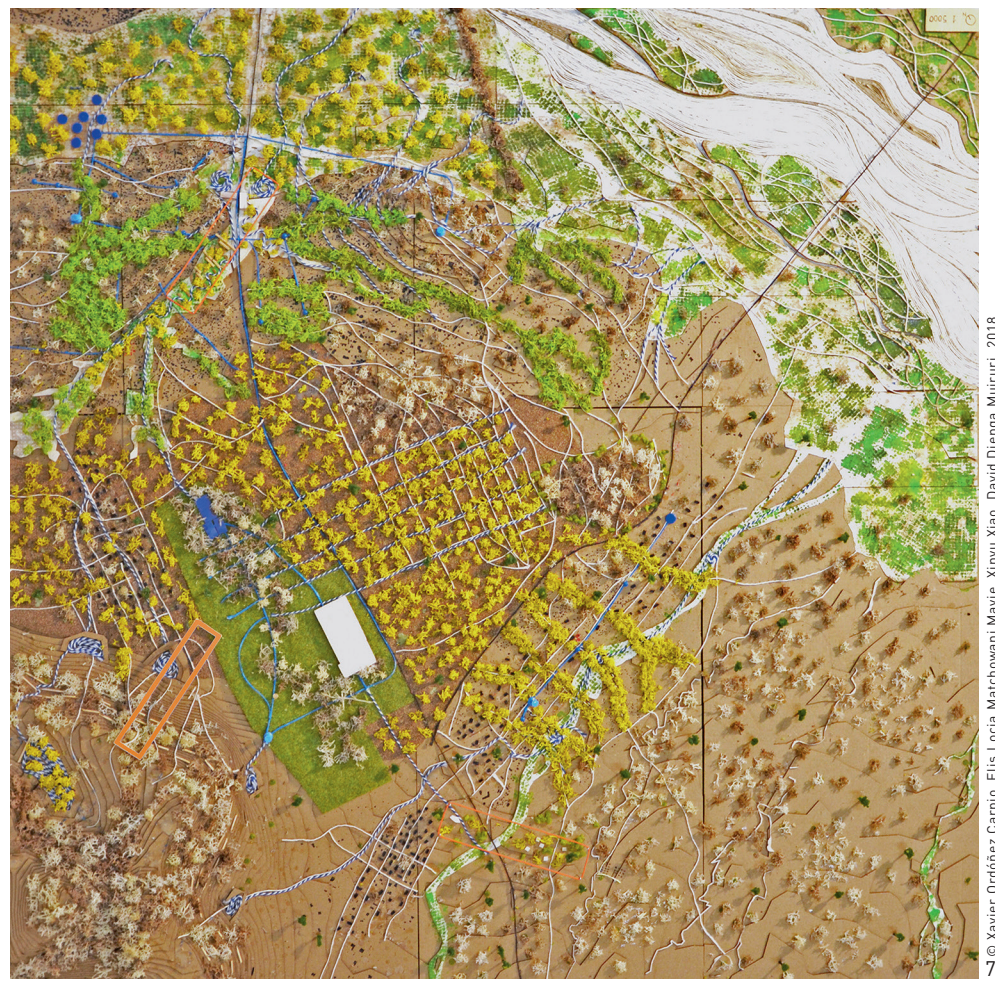

角度探讨了生态与经济、环境与城市的均衡发展。同时, OSA也一直将 社会维度视为应对城市危机的重要手段, 因为城市危机中往往涉及许 多紧迫的社会问题。例如, OSA就黎巴嫩、约旦、加沙及约旦河西岸巴 勒斯坦难民营的建设与社区问题开展了十余年的研究, 也十分关注圣 保罗地区的流浪者及弗兰德斯地区的贫民窟问题。

OSA的研究和实践案例经常位于那些社会不公现象极其严重的地 区, 这就要求我们必须直面当地的社会生态。在这类项目调研中, OSA 始终秉持一贯立场, 即不对社会问题发表观点, 而是参与到社会问题 中去: 这里的 “参与” 不是指邀请当地居民加人研究与规划工作; 相 反, OSA的研究人员会深度融人当地的社会运动及各类社会政治与空间 冲突, 并努力成为社会运动及公民社团组织的参与者 (而不仅仅是旁 观者）从一而更好地制定改善方案。OSA试图以城市规划专家的身份, 通过空间塑造来缓解这些冲突。在目前许多主流建筑或规划项目中, 社会参与往往意味着摒弃规划设计学科视角 (会不可避免地成为社区 或社会政策制定者、规划倡导者或推动参与者）; 但OSA会有意识地借 助都市主义手段工具, 并秉承着一种列伏斐尔式的理念: 物质空间是 社会实践与空间现实辩证迭代的产物。因此, 在最终方案中, 改善要 素还需与抵抗市场均等化或同质化趋势的措施相结合。这种抵抗措施 自然且必然地取决于对于项目本质的认知和对场地特点的了解。这类 项目均很好地回应了各自的社会与空间背景, 更加因地制宜地制定了 改善方案。

上述理念在OSA的巴勒斯坦难民营项目中得到了充分体现。该项目 environmental and social crises. Water and forest urbanisms explicitly articulate an environmental angle while elaborating approaches of urbanism that balance ecology and economy, environment and city. The social dimension of the urban crisis is no less on OSA's agenda; it has engaged on a number of fronts where social issues are pressing. OSA has worked for more than a decade on development and community issues of Palestinian refugee camps in Lebanon, Jordan, Gaza and the West Bank, engaged with homeless in Sao Paulo and spaces of poverty in Flanders.

OSA is often solicited to places where social injustice is so extreme that there must be a direct focus on social ecologies. What is common in all such investigations is the position of OSA and its members. It reverses the contemporary attitude towards participation. Rather than inviting populations to participate in research and planning, OSA members become literally imbedded in social movements and various sorts of socio-political and spatial struggles. OSA participates - not the other way around. OSA researchers deliberately become members (not mere observers) of social movements and civil society organizations in the elaboration of emancipatory projects. OSA attempts, through working as urbanists, to articulate and give shape to the spatial dimensions of emancipatory projects. OSA distinguishes itself from many mainstream architecture and planning practices for whom social engagement implies abandoning the discipline (inevitably becoming community or social policy developers, advocacy planners, facilitators of participation processes, etc.). OSA deliberately works with the tools and instruments of urbanism and from the Lefebvrian understanding that physical space reflects iterative dialectics between social practices and spatial realities. Resulting projects inevitably combine emancipatory components with resistance against the equalizing and homogenizing tendency of the market. Such resistance, naturally and necessarily goes hand-in-hand with the recognition of inherent qualities and local capacities. Emancipatory projects are context-responsive, embracing the social and spatial.

This is well illustrated by work on Palestine refugee camps that was initiated by the doctoral research of Ismael Sheikh Hasan, On Urbanism and Activism in Palestinian Refugee Camps: The Reconstruction of Nahr El Bared (2010-2015). Hasan was a key activist who steered reconstruction of Nahrel-Bared after its destruction by the Lebanese Army in 2007. Intensive mapping, iterating between social and physical documentation with the inhabitants, served as a register. Projective mapping functioned as a repository of the collective memory of the Palestinian refugee community; it was a reaffirmation of identity, upon which future development was
7. 强化莫桑比克泰德地区开 阔冠林。该研究为哈坦达 阔㝴林。该究为哈坦达 项目中 $5 \mathrm{~km} \times 5 \mathrm{~km}$ 的研究 地块建立了一个1: 5000 的 模型 $(100 \mathrm{~cm} \times 100 \mathrm{~cm})$ 。 该项目建立了一个集水系 统, 在倡导农业集约化的 同时, 也有助于植树造 林。项目还提出将高原上 连续的、多样化的开阔冠 林重新引入支流流域和山 林重新引入文流流域和山 坡, 直至此西河。当地 的主要聚落同时集中在此 开阔冠林之中

8. 约旦加沙难民营的景观框 架。通过细致研究加沙难 民营的场地特征, 项目创 建了一个渐进式的空间结 构。拄释性地图绘制反映 了社会需求和期许。项目 继而确立了加沙难民营改 继普计故立了加沙难民营改 善计划的空间框架。作为 UNRWA早期难民营改善
计划项目之一, 社会计划 被纳入此项目的空间构建 体系。通过将社会和生态 因素相结合, 场地重新融 入当地景观之中。

7. Intensifying the Open Forest Canopy, Tete Region, Mozambique. The $5 \mathrm{~km} \times 5 \mathrm{~km}$ model for the Nhartanda project at the scale 1:5,000 $(100 \mathrm{~cm} \times 100 \mathrm{~cm})$. The project establishes a water harvesting system that, while allowing that, while allowing agriculture, contributes agriculture, contributes
to reforestation. This re establishes a continuous, yet now diversified open forest canopy from plateau, to tributaries and to slopes to the Zambezi. The open canopy forest embodies the main settlement structure.

8. Landscape Frame for Gaza Camp, Jordan. A careful reading of the Gaza Camp revealed it as an incrementally articulated spatial structure. Interpretative mapping allowed for understanding social needs and desires. The subsequent project substantiated the definition of a spatial frame for the Gaza Camps Improvement Program. As a complement to earlier UNRWA's camp improvement programs, in this case, social programs are embedded within a spatial project. The project re-embeds the camp within its landscape, coupling social and ecological agendas. 

城市建成空间的抗性。 鉴于当地环墇和居民所 西临的安全威肠, 项 面临的安全威胁, 项目 必须考虑纳布鲁斯乡土 聚落错综复杂的网络关 系。该研究聚焦于平日 和战时城市建成环境的 一系列叙事和空间形 态。日常和战时具有两 种不同的行为模式: 具 有明的角为模式: 具

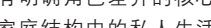
家庭结构中的私人生活 会立即转换为一种与传 统模式相反的集体行为 ( 包括庇护、避难、救 援、通信、隐藏等) 。 基于此, 复杂的城市形 态和建筑将成为可以包 容两种不同类型生活模 式的物质基础。

9. Urban Tissue Resilience During War, Nablus, Palestine. A fictive simulation of the 3D entanglement of the Nablus kasbah was necessary for the research, due to security threats to the fabric and its inhabitants). The study focuses on a series of narratives and spatial appropriations in the urban tissue on ordinary days and during war. The shift between normal time and war switches behavior patterns. Private life in nuclear family structures with articulated gender roles is instantly exchanged for collective practice including sheltering. (n) communication, hiding, etc.) that inverse conventional pattern The complex urban form and architecture is a main asset in this regard, since it allows the accommodation of quite contradictory practices.
来源于伊斯梅尔 - 谢赫 - 哈桑的博士研究《巴勒斯坦难民营的都市主 义与行动主义: 巴里德河难民营的重建》（2010-2015）。2007年，巴 里德河难民营被黎巴嫩军队摧毁后, 哈桑成为了积极推动当地重建的 关键性人物。通过与当地居民一起反复研究社会与物质空间资料, 该 规划项目借由密集的测绘, 保留了巴勒斯坦难民们对这一段难民营时 期的集体记忆, 以重塑人们的身份认同感, 未来的重建活动也在此基 础上展开。其对黎巴嫩政府制定的毫无特色的重建计划发出质疑, 并 推动了与联合国近东巴勒斯坦难民救济和工程处（UNRWA）的谈判。 2014年, 通过与WIT建筑事务所和UNRWA合作一一亦是UNRWA发起的 “难民营改善计划”项目之一—OSA在加沙难民营（又名希森营）的 城市设计工作坊中再次运用了这一经验：基于深人细致的社会与物质 空间测绘（包括一切社区需求、倡议与期许）, 项目团队提出的空间 框架充分体现了难民营的特征, 为改善工作指明了方向, 成为了一种 对场地曾经的空间结构进行重新诠释的社会实践（图8）。

阿比德 - 科塔纳在其正在进行的博士研究《描绘 “坚固” 的地图 集：战时的空间、人与韧性》（2015-2019）中，对 “抗性” 的概念 进行了深刻探讨。该研究聚焦于纳布卢斯地区的分层空间结构, 其是 千百年来历经建设、毁坏、重建、适应与改变等过程的结果。该项目 表明, 城市结构是一种空间综合体, 其产生于社会实践和物质特质之 间的辩证迭代过程; 此外, 项目还发现城市空间对具有不同含义的过 程表现出极大的开放性。在日常生活中, 当地的原住民聚落的空间结 构可以被看作是一系列明确社会行为规范的凝结, 涉及公私关系、性

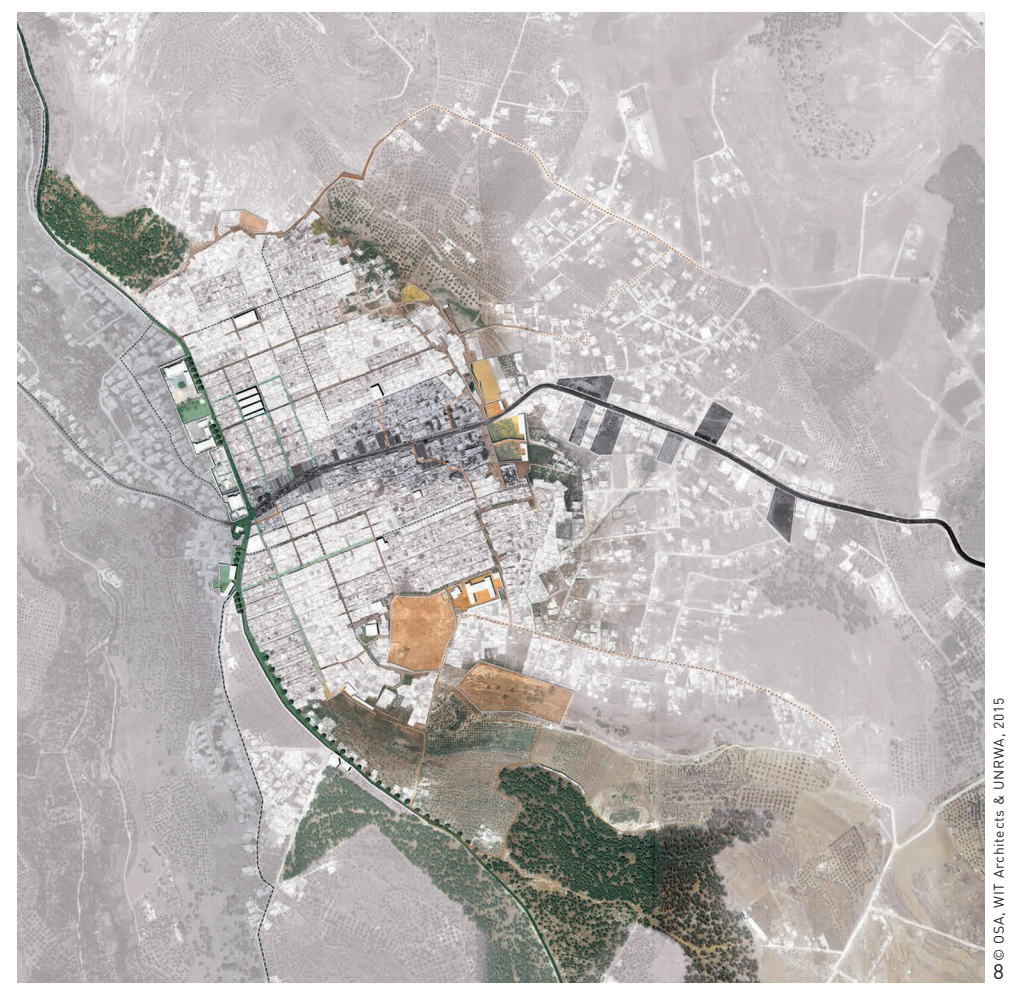

grafted. The register countered generic reconstruction plans by the Lebanese government and steered negotiations with the United Nations Relief and Works Agency for Palestine Refugees in the Near East (UNRWA). A similar experience was replicated by OSA in a 2014 urban design workshop, co-produced with WIT architects and UNRWA, on Gaza Camp (officially Husn Camp, Jordan) as part of the Community Improvement Program of UNRWA. Meticulous social and physical mapping (including all community needs, initiatives, and desires) was translated into a spatial frame that expressed the camp's character and gave direction towards improvement. Reinterpretation of previous spatial structures which hosted social practices became the project (Fig. 8).

The notion of resistance is most tangibly explored in the ongoing doctoral work of Abed Kittana, Making the Atlas of "Sumoud": Space, People, and Resilience under War Conditions (2015-2019). The research focuses on the layered spatial fabric of Nablus, literally an accumulation of millennia of constructions, destructions, reconstructions, adaptations, and alterations. Nablus makes evident the fact that urban fabric is a spatial synthesis, resulting from a dialectic iteration between social practices and physical qualities. It also reveals an amazing openness of space towards different signification processes. In normal everyday conditions, the
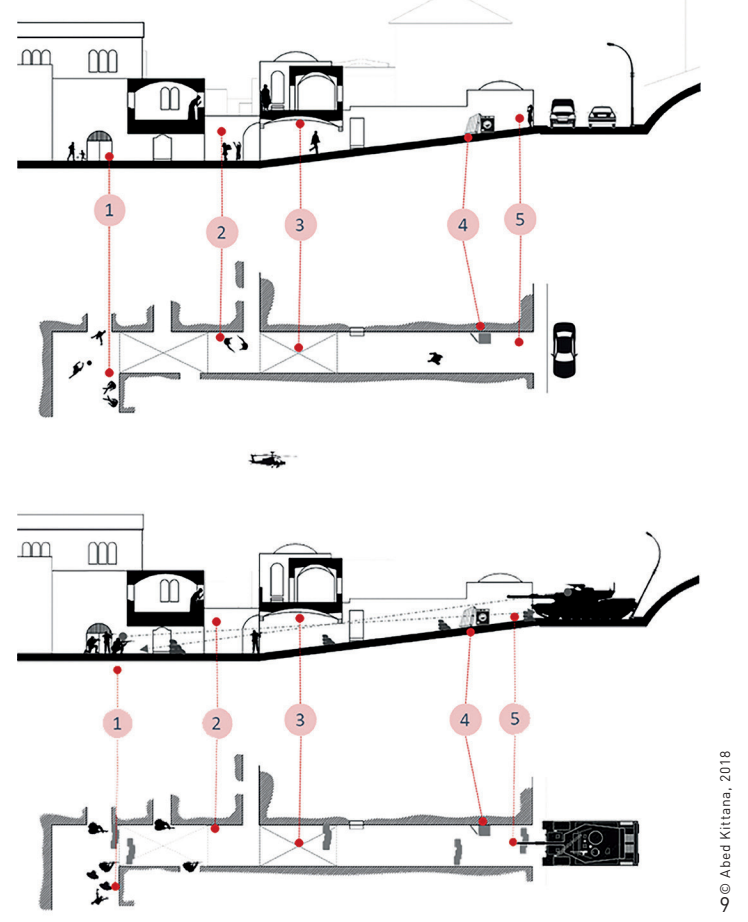


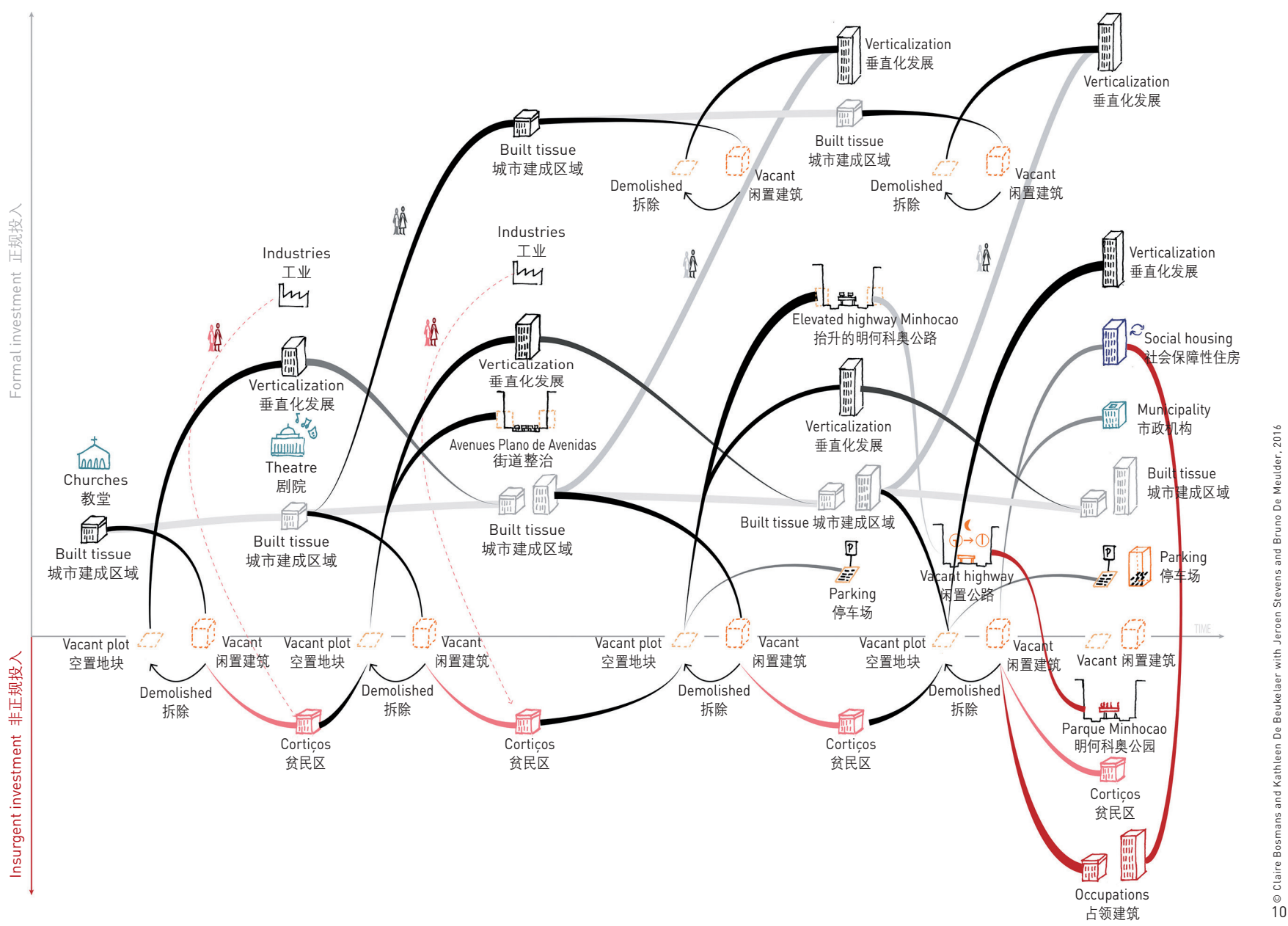

别、经济与商业交易等方面; 在突发情况下 (例如遭受以色列军队越 发频繁的空袭时), 所有的规定、规范和行为准则都被彻底推翻。战 争打破了秩序, 一夜之间颠覆了空间意义; 战争重塑了空间, 这种改 变体现了空间本身所具有的韧性与灵活性, 这二者都是组成 “抗性” 的必备特质（图9）。

杰伦 - 斯蒂文斯的博士研究《城市中被占领的建筑: 圣保罗市中 心的城市运动和都市主义原型》（2013-2018）聚焦于那些为无家可归 者争取城市权利的占领运动: 人们在圣保罗的街道上游行抗议, 并发 起了占领市中心空置建筑的运动, 以切实的行动争取 “城市权利” 。 在政府未能履行其职责解决住房问题的背景下, 此类运动不仅重新定 义了 “住房”，还向人们 “提供” 了住房。通过一系列对建筑的人 侵与占用、逐步挪用与改造运动, 流浪者以实际行动为自己找到了容 身之所。该研究探讨了无家可归者通过社会运动改造圣保罗市中心空 置物业的途径，及其与空间建设的内在关联。事实上，在持续的资金 投人和不可避免的衰败的双重推动下, 城市 (中心区) 经历着不断重 塑; 新的建设模式和方案也会随之不断产生, 来满足公众对于世界的 崭新期许。这一 “投资一衰败一再投资” 的无止境循环非但不会造就 spatial constellation of its kasbah can be read as a solidification of quite articulated social conduct rules (gradients of publicprivate relations, gender, economic and commercial exchange, etc.). Extraordinary conditions - such as increasingly fatal raids by the Israeli Defense Forces - turn the entire system of regulation, codes, and behavior upside-down. Wars break rules. Spatial signification switches overnight from black to white. War amplifies interaction in space. Such elasticity demonstrates how space itself contains a form of resilience and agility, both necessary for resistance (Fig. 9).

The doctoral research of Jeroen Stevens, The Occupied Architecture of the City: Urban Movements and Prototypes of Urbanism in Central São Paulo (2013-2018) concentrates on occupation movements that claim the right to the city for the homeless. They demonstrate on São Paulo's streets and importantly, literally practice "the right to the city" by occupying vacant structures in the city center. The movements - as substitutes for the State that hold responsible for the right to housing - redefine housing and "provides" it. The homeless house themselves in a movement of movements, actions,
10. 巴西圣保罗中心的建筑 闲置和占用情况。圣 保罗市倩况。圣 保罗中心经历了一连 事的投资建设与改造活 动, 城市建设拆除与闲 置的现象并存。如今, 圣保罗市中心出现了一 系列空间冲突: 既有全 新的建筑, 也有历史悠 久的建筑; 既有重新投 资的项目, 也有被彻底 废弃的项目; 既什现出 了绝对的控制, 既体现 出了矛盾的执择。这恠 出了矛盾的抉择。这既 是一种社会生态场景, 也是一种争议性空间; 不同的元素在这里共 存, 彼此相互容忍且又在 一定程度上存在竞争。 and Occupancy in São Paulo's Center, Brazil. The center of São Paulo is understood as repository of successive waves of intervention and investment with the simultaneous demolition and vacancy demolition and vacancy of its accumulated patrimony. Today, the center of São Paulo assembles a range of spatial conditions from the brand new to the centuries-old, from the reinvested to abandoned and from abandoned and from the over-defined to ambivalent. This sets a socio-ecological scene, a contested space, in which different groups are co-present, partially tolerating each other, and partially contesting each other. 
11. Social Support Strategies for Housing in Cuenca, Ecuador. In the peri-urban areas of Cuenca, families manage migrants' remittances by building housing. Family and neighbors can be summoned to minga la traditional regime of cooperationl at critical stages, such as casting foundations After a foundations. After main house is built,
remittances are mostly invested in land. The variety of altitudes of the acquired new plots provides the household with a diversity of resources. To make use of those resources, house household members engage in journeys that in a micro-scale reproduce the vertical control of ecosystems.
无缝衔接的城市结构, 反而会形成杂糅着大量对立的异质性元素和冲 突的拼贴肌理。这些循环往复的过程一一占有与空置、新兴与陈旧、 保卫与遗弃一一为新城市的诞生提供了契机与突破口（图10）。

莫妮卡 - 里维拉 - 穆尼奥斯以 “分散城市：帕乌德河流域的间隙 景观” (2014-2019) 为题，对位于厄瓜多尔安第斯山区的昆卡市周 边地区进行了研究。昆卡市中心是经联合国教科文组织认定的历史城 区，快速的城市化进程推动着当地的士绅化发展。不同于其他城市扩 张研究, 该研究聚焦于当代动态因素与延续了数百年的古老传统之间 的角力一一被此种角力重塑的城市边缘地带成为了千篇一律的正规城 市和保持本土风貌之间的分割线, 其周边的良田被不断侵占开发为私 人庄园。这些间隙地带为城市开发中的无家可归者、贫穷的白人, 以 及原住民提供了逃离法规及传统 (与苛捐杂税) 束缚的机会。这些一 直以来被视为不重要的地带一一各色人等在此混居、获得租用土地, 并形成了独特的人居文化一一既存在着极大的不稳定性 (往往需要全 部家庭成员在多地进行劳作 ), 同时也具有相当的灵活性（人们可自 行决定是在庄园劳作、到城中市场贩售农产品、季节性地在滨海种植 园务工，或是经营小生意等）；居民们一面自力更生，一面依赖外部 力量。土地和祖产 (如住房、宅地、林地、灌溉系统与平坦的农田 等）既是人居文化的重要组成部分，也是居民们赖以抵御无差别郊区 城市化浪潮的物质基础（图11）

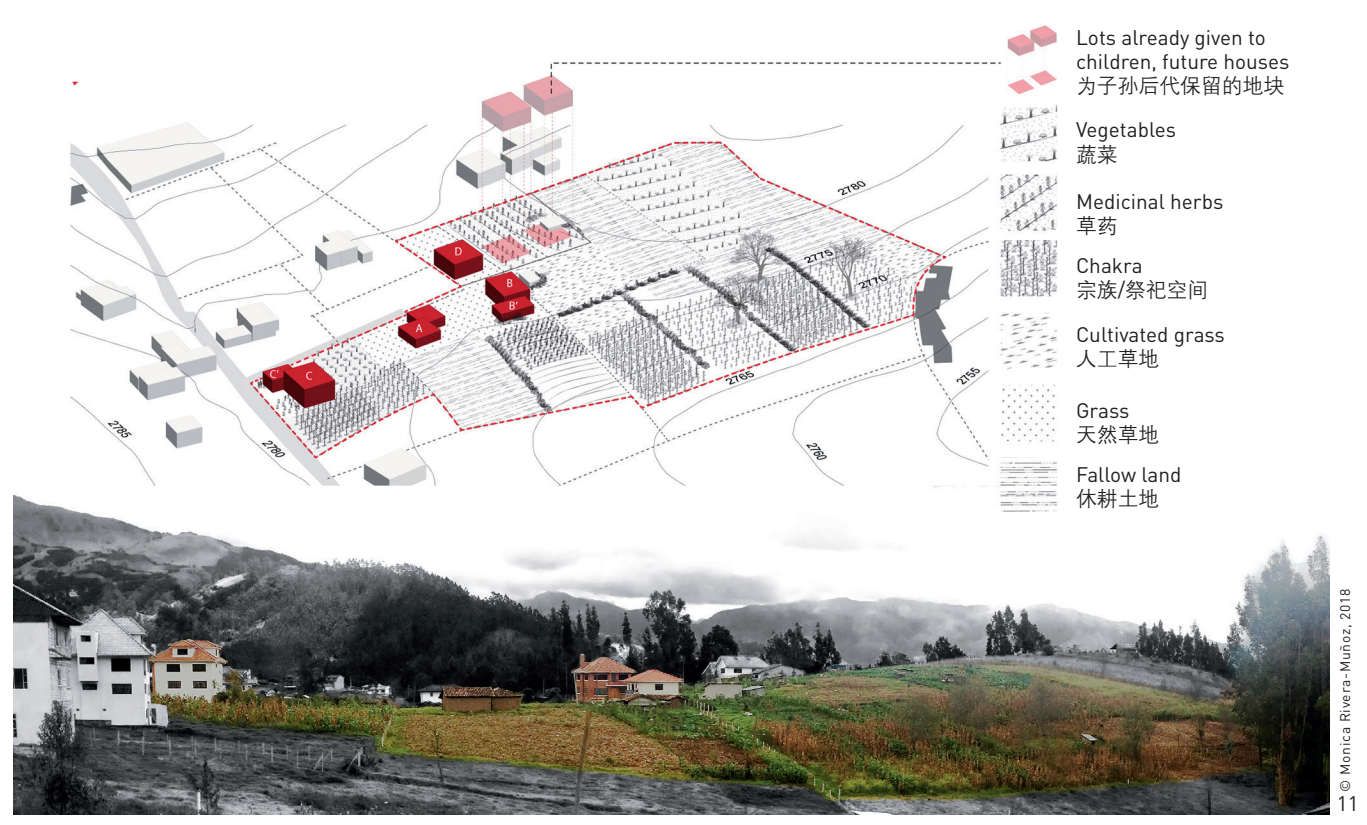

demonstrations, building invasions and occupations, and gradual appropriation and transformation. The research explores how the center of São Paulo's vacant patrimony is transformed by social movements of homeless and the inherent interrelation to spatial development. Indeed, the city (center) is continuously reproduced by successive investment - that always introduces new development models and answers to new expectations of belonging to the world — and inevitable deterioration. The eternal loops of investment, decay, and reinvestment do not produce a seamlessly matching fabric, but rather a thick juxtaposed patchwork of heterogenous and contradictory elements. It is in the interstices of the claimed and vacant, new and old, guarded and left-over that are continually reproduced opportunities and openness for another city to emerge, as in a Sisyphusian endeavor (Fig. 10).

Monica Rivera Muñoz in Disper[city]: A Study of inbetween Landscapes in the Paute River Watershed (2014-2019) studies Cuenca's peripheries in Ecuador's Andean highlands. Fast urbanization occurs in the slipstream of gentrification of the UNESCO-recognized historic center. Unlike most studies on sprawl, the study focuses on the interplay of contemporary dynamics with centuries-old mechanisms that formed the region's hilly peri-urban development - torn between the formal colonial city and the native territory, and beside the fertile lands that haciendas appropriated on the plains. It is in such inbetween territories that colonial outcasts, impoverished whites, and natives escaped the yokes of regulation and tradition (and taxes). Such secondary spaces where historically the hybridized population found ways to acquire land tenure and generate a unique settlement culture, are always precarious (requiring a multitude of activities on a multitude of locations, with the effort of all family members), but also always flexible (weighing the opportunity of labor on haciendas, selling produce on urban markets, seasonal migration to coastal plantations, developing small enterprises, etc.). They are always torn in between selfreliance and dependence on outside forces. Land and patrimony (houses, homesteads, afforestation, irrigation systems, stonecleared fields, etc.) are essential to the settlement culture and are the major assets the local population has to contest and resist generic processes of suburbanization (Fig. 11). 


\section{5 与水共居：哥伦比亚波哥大稀树草原地区城市化的新思考}

作者: 克劳迪娅・露西亚・罗哈斯・博纳尔 ${ }^{2}$

1930年以来, 无序的城市化进程一直在急速侵占乡村的土地, 并 一步步虫食水体、洪泛平原与湿地, 导致了生态系统的碎片化。农业 用地与波哥大河洪泛平原上的土地很快成为投机买卖的对象; 同时， 整个地区的人口膨胀与住房短缺问题也日益严峻。波哥大大都会区的 每日生活用水需求量高达 145 万立方米, 其中 $80 \%$ 以上由钦加萨-帕拉莫 自然保护区 (一个位于安第斯山脉的高海拔富水生态系统) 供给; 但 受气候变化影响, 该生态系统目前也苃岀可危。如今, 波哥大河沿岸 的开发建设压力与饮用水需求仍在不断增加, 生物多样性也正在加速 减少。

波哥大的土地价格与政策因素致使社会保障性住房只能建在洪泛 平原之上 (如丰萨市和莫斯奎拉市)。这些建设开发与平原上历史悠 久的农业传统相冲突, 并危及到了具有宝贵生态价值的瓜里湿地。

该区域所面临的问题是如何重构城市肌理、生产性景观与生态系 统之间的联系。改造地形与开发新的居住形式将进一步使城市建设更 好地与环境融合。从历史上看, 改造地形一直是人居建设过程中不可 或缺的手段: 早在哥伦比亚被西班牙殖民之前, 当地先民便已能够利 用自然循环来修建精巧的脊状梯田系统, 这既提高了作物产量, 又 保护了聚落免遭洪水侵袭。此次设计调查对当地系统进行了逐段诠 释, 并在波哥大河的瓜里湿地与波哥大的城市建设区域之间建立谢特特罗伊与艾尔-哈托两条步行线路, 以在水域及陆地间创造清晰的连接 ( 图12)。

\section{Settling with Waters: Reconceiving Urbanization in the Sabana de Bogotá, The Republic of Colombia}

Author: Claudia Lucia Rojas Bernal ${ }^{2}$

After 1930, uncontrolled urbanization in the rapidly consumed rural land and systematically encroached water bodies, floodplains, and wetlands, resulting in a fragmented ecosystem. Agricultural lands and the floodplain of the Bogotá River soon became objects of speculation. Simultaneously, the population as well as the overall housing shortage increased continuously. Metropolitan Bogotá has a domestic water demand of 1.45 million $\mathrm{m}^{3} /$ day. More than $80 \%$ is derived from the Chingazá Páramo, a high Andean ecosystem with a large water-storage capacity, but which is critically endangered by climate change. Today, development pressure along the Bogotá River and the demand for drinking water is increasing, while the loss of biodiversity is accelerating.

Land prices and policies of Bogotá have displaced social housing to municipalities in the floodplain, like Funza and Mosquera. Their rapid development conflicts with the deep agricultural identity of the plane and compromises the preservation of the ecologically valuable Gualí Wetland.

The region requires a new relationship between urban fabrics, productive landscapes, and ecological structures. Urbanization can become more settled in the environment by manipulation of topography and new housing typologies. Historically, topographic manipulation was part-and-parcel of settlement development. The pre-Hispanic population already applied sophisticated systems of ridged fields, which took advantage of natural cycles to both
(2) 作者已于 2017 年取得 博士学位; 指导教师: 布鲁诺、德.缪德尔、凯 布鲁诺・ 利.香农。

(2) The author completed her doctorate in 2017; promoters: Bruno De Meuder and Kelly Shannon.

12-1. 与水共居：“软性人 造”水景观: 谢特一特 步道沿途的 “与水共 居” 景观。二者均位于 瓜里湿地与波哥大城区 之间, 面临着建设开发 的压力。设计方案使生 产性景观、当地文化与 人居环境相互融合。

12-1. Settling with Waters: "soft engineered" wate landscape. "Settling with waters" in Vereda Siete Trojes and Vereda el Hato. Both face development pressure and are located between the urban tissue and the Guali Wetland. They align productivity, culture, and settlement.

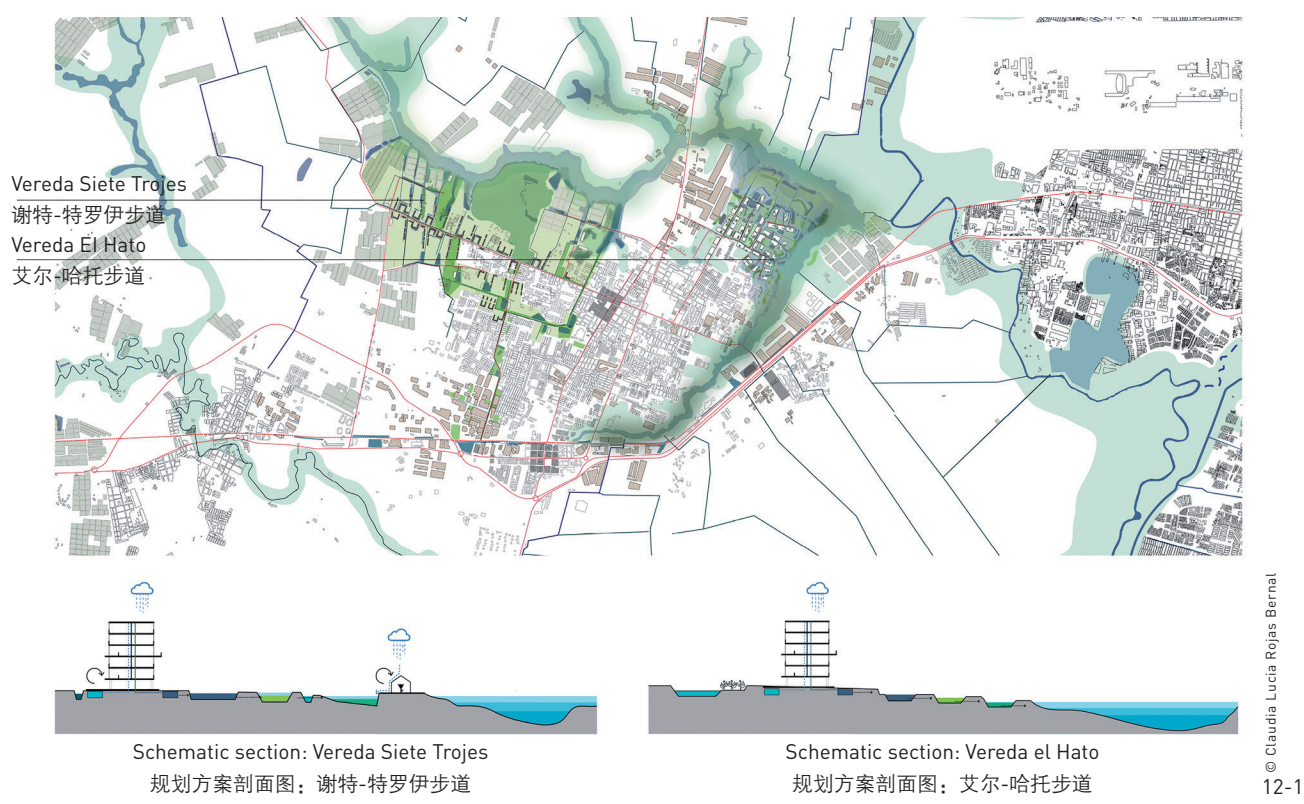


12-3. 艾尔-哈托步道: 城市平 台与扩张的湿地。在艾 尔-哈托沿线, 经过重新 改造的地形形成了一系 列平台, 新的湿地、生 产性景观与住宅区在这 些平台上桑育成形。

12-2. Vereda Siete Trojes: preservation of agriculture and agriculture and definition of wetland edges. In Vereda Siete Trojes, the irrigation system is manipulate integrating a new agricultural order that simultaneously functions as a structural framework for housing.

12-3. Vereda el Hato: urban platforms and extended wetlands. In Vereda el Hato, the topography is reconfigured to organize a system of platforms that accommodate new wetland areas, productive landscapes and housing typologies.
对良田及瓜里湿地的保护是这两条线路均需要面对的重要问题 基于对当地细密的灌溉网络的深人研究, 设计团队提出了土地分割系 统优化方案，使新型农业及住房开发活动与自然的动态过程相协调, 使基础设施具备多种功能（如洪水防控、水产运输、提升生物多样 性、垂钓或休闲娱乐）; 新的水系统由分散的水管理单元构成，并在 局部设计中将新的工程措施与景观项目相结合，例如，将雨洪管理功 能和灰水处理池与林荫步道的设计相融合, 使之既能作为生态设施, 也能充当游憩空间; 最后, 灰水通过花田得到净化, 并循环利用为生 活用水（则所和洗衣用水），或被排人湿地以在灌溉网络中再次循环 利用。该设计调查还考虑了气候变化的可能影响及社会保障性住房极 度短缺的问题。方案最终建立了新的城市与自然生态，以使波哥大地 区在应对当前的挑战时具有更强的社会与生态韧性。

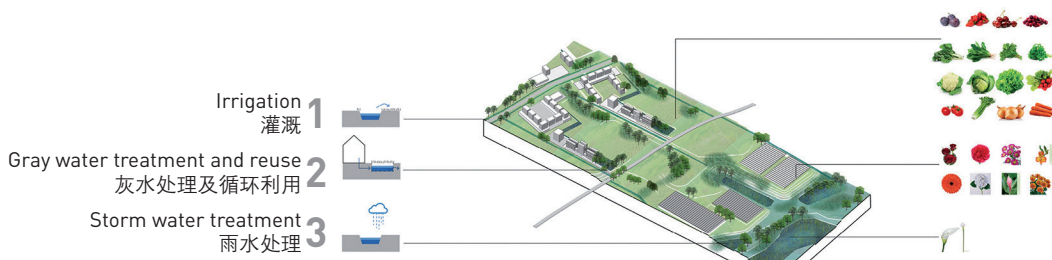

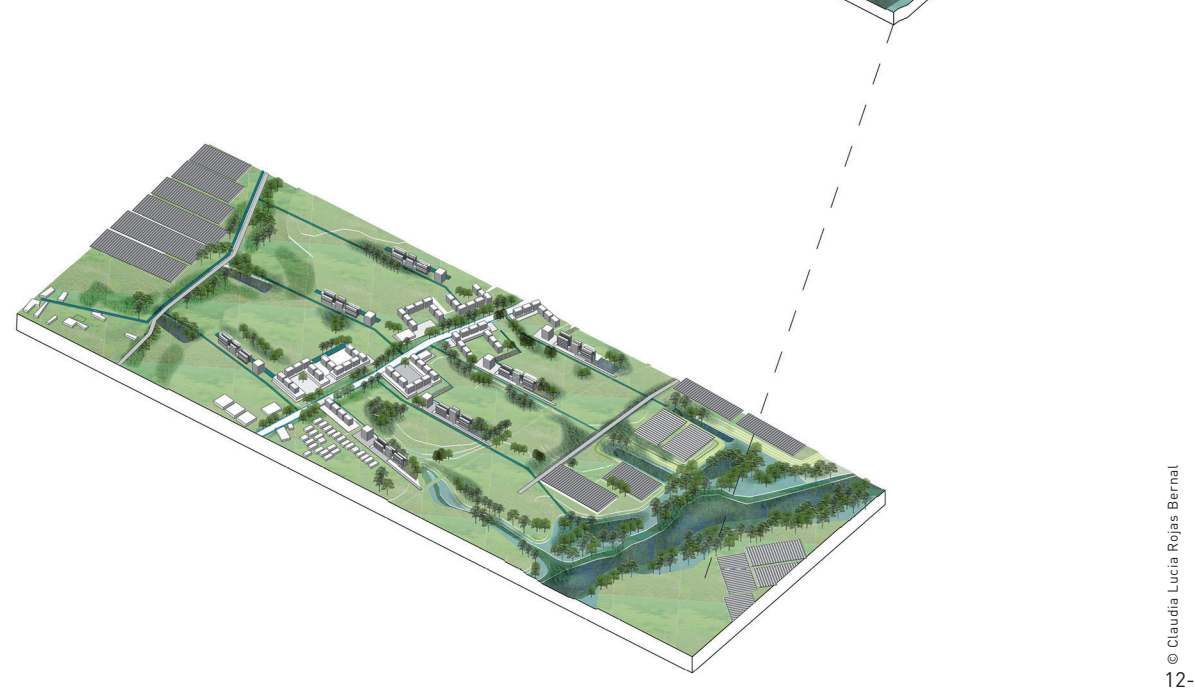

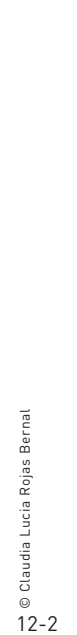

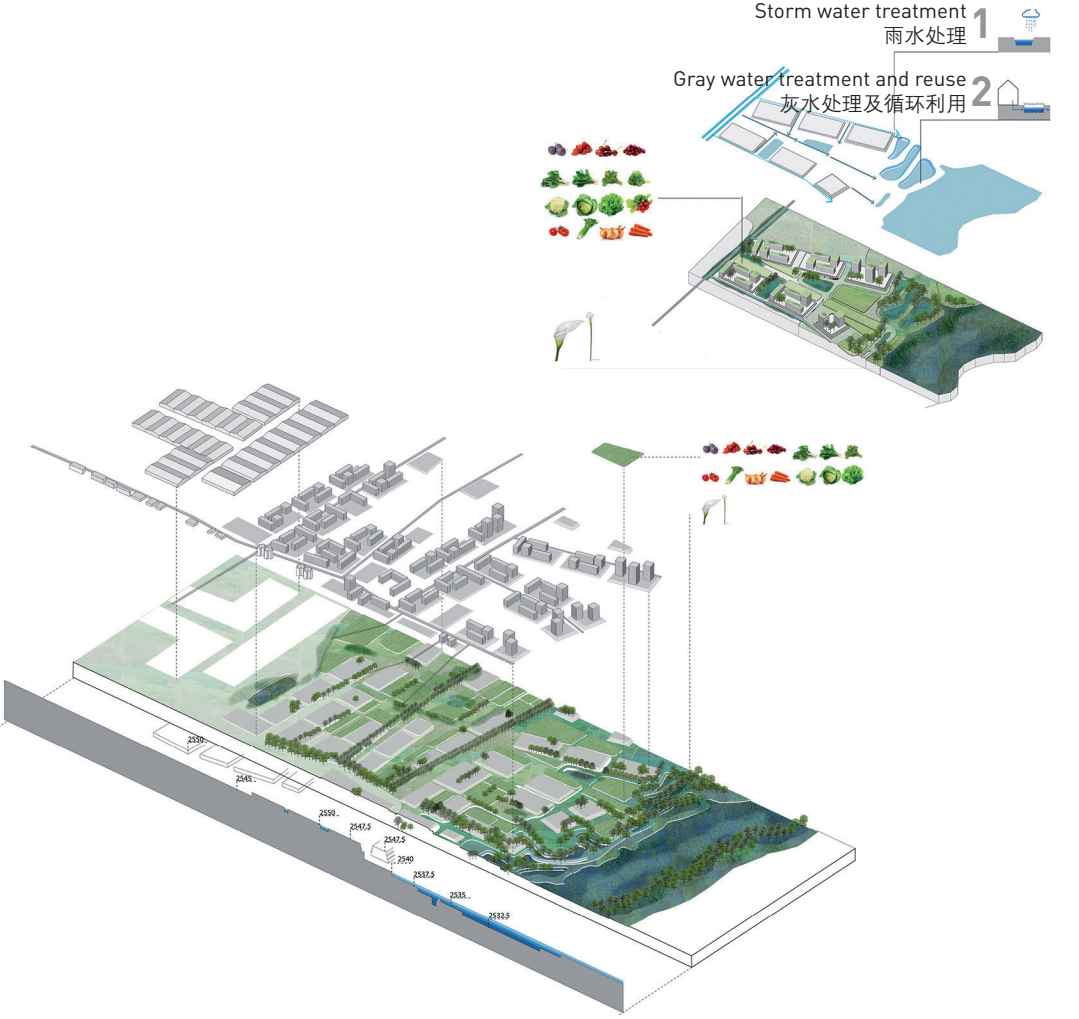

$12-3$ 


\section{6 秘鲁北安第斯山脉卡哈马卡废弃矿山的生态设计}

作者: 玛格丽塔・马塞拉 ${ }^{3}$

自1993年起, 秘鲁卡哈马卡地区开始对雅纳科查矿山（一座大规 模的表面堆浸式混合金矿) 进行开采, 并因此对马什孔流域的河源景 观造成了巨大改变。该矿山的海拔高度为 $3500 \sim 4150 \mathrm{~m}$, 是当地独特 的哈尔卡高原生态系统的一部分, 这种生态系统能在雨季吸收和储存 雨水, 使下游凯楚阿生态区 (海拔2 $700 \sim 3500 \mathrm{~m}$ ) 的河流在旱季免于 干涸; 凯楚阿生态区中分布着大量乡土聚落 (一种依赖农业维持生计 的大型家族式聚落形式），卡哈马卡城区则坐落在山脚下。金矿开采 预计于 2025 年终止; 如果到矿山实际关闭时才开始对废弃矿山进行规 划, 那么, 当地的社会及生态系统将受到灾难性的损害。卡哈马卡地 区废弃矿山韧性提升需要一种能够兼顾矿山、城市与乡村问题的整体 性（设计）方案。

针对项目所在区域的多山地形, 设计在哈尔卡与凯楚阿生态区的 小型空间中营造了多样化的农业生态区。在西班牙殖民统治之前，乡 土聚落分布在位于不同生态层的 “垂直空间系统” 中, 以便最大限度 地利用不同农业生态区的资源 (图13)。历史上, 这种聚落分布在不 同海拔高度的山区中, 且建立了能够自我更新的土地生产与水资源管 理机制。然而, 凯楚阿河谷与哈尔卡高原上当前发生的巨变极大地破 坏了当地历史悠久的山地特色景观。

在过去 25 年中, 卡哈马卡地区的生态环境变化比此前600年间发生 的变化都要剧烈。借助现代地表重塑技术, 人类可以改造一切原本不 利于建设开发的环境。城市定居点的扩张及其对土地的占用、采矿作 业、草场放牧、人工造林等活动均对乡土聚落造成了威胁，并导致了 严峻的资源竞争 (主要针对土地和水)。不同生态层上或同时发生、
6 Designed Ecologies of Post-Mining Cajamarca, Peruvian North Andes, Perú

Author: Margarita Macera ${ }^{3}$

Since 1993, Cajamarca (Perú) hosts Yanacocha, a compound of large-scale surface heap-leaching gold mines. Its extraction radically transforms the headwater landscapes of the Mashcon Basin. Positioned between 3,500 4,150 meters above sea level, the mines overlap with unique jalcas ecosystems that absorb and store water during rainy seasons, while securing a base water flow for the downstream Quechua ecoregion (altitude 2,700 3,500 m) during dry seasons. Dispersed in the Quechua ecoregion are nested a vast amount of caseríos, clusters of extended-family houses with subsistence economies. The city itself, Cajamarca, lies in the foothills. Mining operations are projected to cease in 2025. It would be fatal for the region's social and ecological systems to wait until actual mine closure to envision post-mining scenarios. Cajamarca's post-mining resilience indeed requires anticipation through a (design) perspective that holistically addresses mining, urban, and rural domains.

The mountainous topography sets up a variety of agroecological zones compressed in small spaces among the Jalca and Quechua. Since pre-Hispanic times, caseríos are dispersed in "vertical archipellagos" across different ecological floors to tap into the maximum of resources from different agroecological zones (Fig. 13). The dispersion across mountains altitudes historically established self-renewing systems of land production and water management. However, the current rapid transformations of the Quechua valleys and Jalca plateaus distort the qualities acquired by the mountainous landscapes over the longue durée.

Cajamarca's ecologies changed more in the last 25 years
(3) 作者为OSA成员, 目前 博士学位在读; 指导教

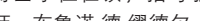
的鲁诺

(3) OSA on-going doctorate; promoters: Bruno De Meuder and Kelly Shannon.

13. 垂直空间系统。散布于山 区之中的乡土聚落, 通过 自给、互惠与合作的社区 运作模式传承了数百年。 这些修建有灌溉系统和梯 田的聚落, 和周围的乡土 植被、哈尔卡河源、河 植被、哈尔卡河源、 流、支流水系及天然水域 融入到当地环 境之中。

13. Vertical archipelagos. For centuries, Cajamarca's caseríos inhabit the mountains in dispersed communities within subsistence, reciprocity. subsistence, reciprocity, and collaboration. These settlements, with sometimes irrigation systems and terraces, inscribe themselves seamlessly with the landscape with its native vegetation, headwater jalcas, rivers, tributaries, jalcas, rivers, tributaries and natural pools.

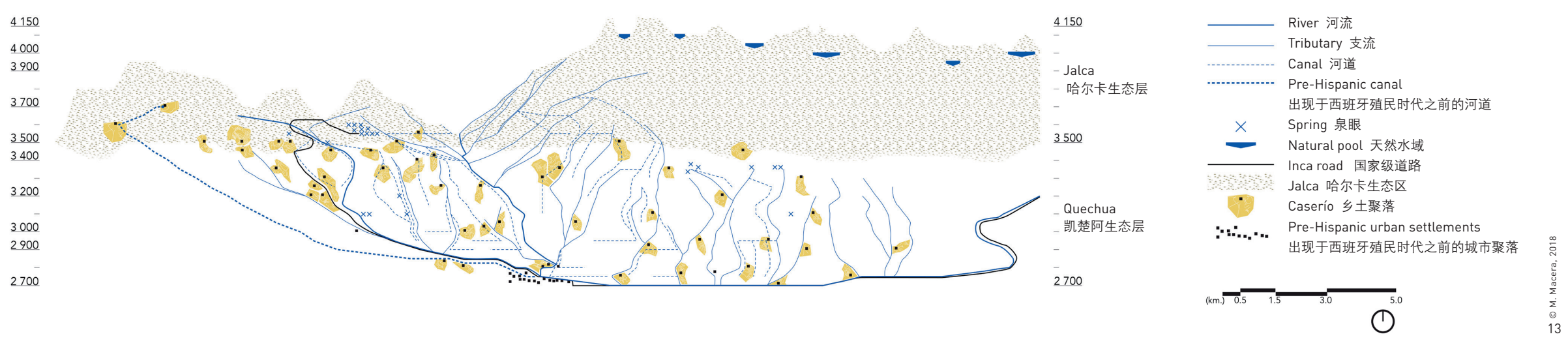


14. Colonization of ecological floors. The spreading of surface mining, urban tissues, pines, eucalyptus, and grazing pastures throughout the basin has detrimental ecological effects. ecological effects. Supported by modern (t) continuous expansion of such land occupation demands everincreasing volumes of water and surface.
或未经协调的景观改造实践，都无一例外地会对自然资源造成不可忽 视的破坏，也会影响人造生态系统的效率及可持续性（图14）。

尽管关闭卡哈马卡矿山的确是出于缓解生态灾害的考虑，但其 所采用的手段并未重点考虑如何保留空间特色。若要取得良好的环境 效益，所采取的干预性区域整治方案需采用顾及所有尺度的设计战 略。对于卡哈马卡矿山而言, 在关闭后进行全面的景观修复是不切实 际的; 设计策略需要将河源、乡村和城市的生态环境视为一个整体来 考虑。将矿山看作一种过渡性的土地利用形式, 既可以维持矿山开采 现状, 也可以解决未来重点关注的社会生态学方面的问题。借助现代 化的地形塑造和采矿机械, 当地传统的梯田修建及水资源管理技术可 以与大尺度地形营建相结合：例如，可以将开采基础设施中的 “运料 路” 逐步改造为水渠，使当地河源与酸化的开采废水相隔离; 此外, 通过在一种安第斯山脉地区常见的精巧梯田 (亦是一种社会基础设 施）上进行植树造林，可有助于缓解凯楚阿生态层的水土流失问题。 这些被改造的梯田还可以为乡村社区提供必需的基础服务。通过对流 域内的不同生态层进行空间重塑, 不仅能够提升生态效益, 还能够将 矿山的关闭转化为提升卡哈马卡地区韧性的切人点。 than in the six preceding centuries. Modern earth moving technologies have colonized locations that would otherwise be too hostile for human occupation. The extensive and landconsuming settlements of the city, mining operations, grazing pastures, and planted forests is in opposition with the logics of the caseríos, which results in a harsh competition over resources, mainly land and water. (Un)synchronized landscape practices across the different ecological floors not only have a tangible impact on natural resources, but also affect the efficiency and sustainability of man-made ecologies (Fig. 14).

While mitigation of ecological hazards is a concern of Cajamarca's mining (closure) operations, spatial quality remains only a by-product of technique. The intentional organization of the territory linked to environmental performance requires design strategies across scales. Full landscape restoration is not feasible after mining closure in Cajamarca. Re-calibration of (new) headwater-rural-urban ecologies seems a more relevant strategy. By considering mining as a transitional land-use, postmining scenarios can simultaneously address short-term mining operations and broader long-term socio-ecological concerns. Reinterpretation of indigenous land-terracing and water management can overlap with large-scale landforms constructed by modern earth-moving and mining machinery. Mining infrastructure such as "haul-roads" can progressively turn into waterways and isolate headwaters from sources of acid mine drainage. Meanwhile, an explicit design of andenes (Andean terraces) of social infrastructure can accentuate Quechua ecological floors within larger afforestation strategies to address erosion. These enmeshed andenes would redeem the lack of basic services in rural communities. Among the basin's various ecological floors, design can orchestrate the reshaping of space with beneficial ecological performance and mining closure can become an entry-point to strengthen Cajamarca's resilience.

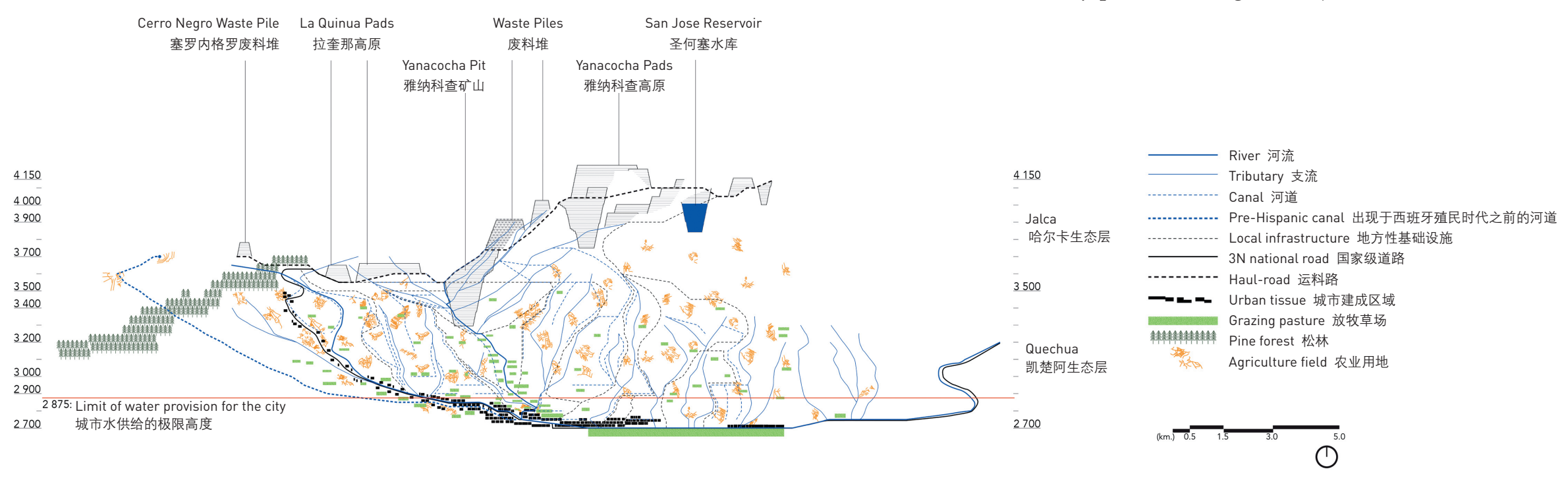


7 太湖流域：苏州河的零碳韧性轴线之转型

作者：萨拉・范・德・费尔德 ${ }^{4}$

鲁汶大学2018年春季景观都市主义设计课程 ${ }^{5}$ 对太湖流域内高密度 的城镇化水文环境进行了深人研究。该课程选取了一个 $140 \mathrm{~km} \times 10 \mathrm{~km}$ 的区域作为研究对象, 探讨了江南地区 (字面意思为 “长江以南地 区”）圩田系统未来的区域发展愿景。设计策略不仅遵循生态重组原 则, 还通过融人形态学与类型学方法来制定兼顾消耗性与生产性景观 的发展规划。太湖流域以低洼的圩田景观为主，其上下游的水利结构 各具特色且都面临着严峻的挑战。流域上游的太湖为 1000 万人口提供 了饮用水源, 也是当地重要的旅游与渔业资源。但近年来, 湖区周边 的工业和城市的飞速发展带来了前所未有的负面影响，包括湖体蓄水 能力下降、严重的水污染、湖水水位上升、洪泛加剧等。而在流域下 游, 连续的沿海堤防建设与土地开旺活动使这一带景观层次变得愈加 复杂, 目前的沿海堤防是长达 $11000 \mathrm{~km}$ 的中国东海海域 “海上新长城” 的重要组成部分

如今, 在太湖周边许多衰落的渔村中正在发生的逆城市化进程为 当地的水环境修复与森林生态改善注人了推动力: 通过挖填方作业, 开垦的土地和山坡地带被恢复为林地。在位于太湖与苏州之间的平原 地带重新引人综合性蓄雨水库，可增强下游河流的活力一一根据中国 国家层面出台的“海绵城市战略”，到2020年，城市地区的吸水性下 垫面面积应增加 $20 \%$, 雨水再利用率应达到 $70 \%$ 左右; 修建水库的举措 将有助于调蓄洪水、储存雨水。此外，符合三角洲本土条件的传统雨 洪管理策略也可以被运用到当代的适应性设计中，促使洪涝管理的思 路从“静态化抑制” 向 “动态化调控”转变。

在上海与苏州的中间地带持续上演的高速城镇化以及贯通南北 的超大型基础设施建设, 已使研究区域内的景观连续性遭受了显著破
7 Taihu Basin of China: Requalification of Suzhou Creek as a Zero-Carbon Elastic Spine

Author: Sarah Van De Velde

The spring $2018 \mathrm{KU}$ Leuven design urbanism studio ${ }^{(5)}$ concentrated on the densely urbanized hydrological unit of Taihu Basin. Focussing on a $140 \mathrm{~km}$ by $10 \mathrm{~km}$ transect, a territorial vision for the Jiangnan (literally "South of the River") polder basin's future was explored. The strategy was premised not only on ecological rebalancing, but also framing development with hybrid morphologies and typologies that reconcile consumptive and productive landscapes. The low-lying polder landscape is book-ended by two distinct water structures, each confronted with extreme water challenges. In the west, Taihu Lake supplies drinking for 10 million people and serves as valuable resource for tourism and fishery. Nowadays, however, swift industrial and urban encroachment along its shoreline has culminated in a detrimental mix of reduced storage capacity, severe pollution, rising water level, and increased inundation. In the east, successive coastal defences and land reclamations have shaped a complexly layered landscape. The current coastal defence structure is part of the $11,000 \mathrm{~km}$ long "Great New Wall" along the East China Sea.

In the vision for the basin, on-going de-urbanization of ageing fishing villages around Taihu Lake is taken as an impetus to restore water and forest ecologies. The cut-and-fill reverses former reclamation and mountainsides are reforested. Integrated rainwater reservoirs are re-introduced in the plain between the lake and Suzhou to rejuvenate downstream flows. As part of China's national "sponge-city strategy" - which aims to expand absorbent urban surface by $20 \%$ and re-use approximately $70 \%$ of urban stormwater by 2020 - the reservoirs would mitigate
(4) 作者为人居环境学硕 士、城市化与战略规划 士、城市化与战略规划 年春季设计课程。

2018年春季景观都市主 义设计课程 “城市三角 洲与气候变化”的指导 教师为凯利·香农教授和 斯特凡妮·登斯教授 (中 国野外调查的指导教师 为克里斯汀. 诺夫教授 与弗洛伦斯. 范贝克教 授）：参与学生包括。 授); 参与学生包括:

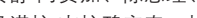
马诺拉·克拉碧安奇、拉 维尼亚·伊森、玛塔·菲 诺泰勒、奥利维亚·米 希恩、阮明强、马尔 瞵·范·胡尔、萨拉·范迪 费尔德、吴雨茜、玛利 亚·扎哈洛娃。

Master of Human Settlement (MaHS) and Master of Urbanism and Strategic Planning (MaUSP), spring studio 2018.

Spring landscape urbanism studio 2018 on Urban Deltas and Climate Change, led by Professors Kelly Shannon and Stefani Dens (Professors Christian Nolf and Florence Vannoorbeeck for fieldwork in Chinal, students: Anshu Ahuja, Chen Sijin. Manola Chen Sijn, Manola Colabianchi, Lavinia Isan, Marta Finotello, Olivia Missiaen, Minh Quang Nguyen, Maarte Van Hulle, Sarah Van De Velde, Wu Yuxi, and Maria Zakharova.
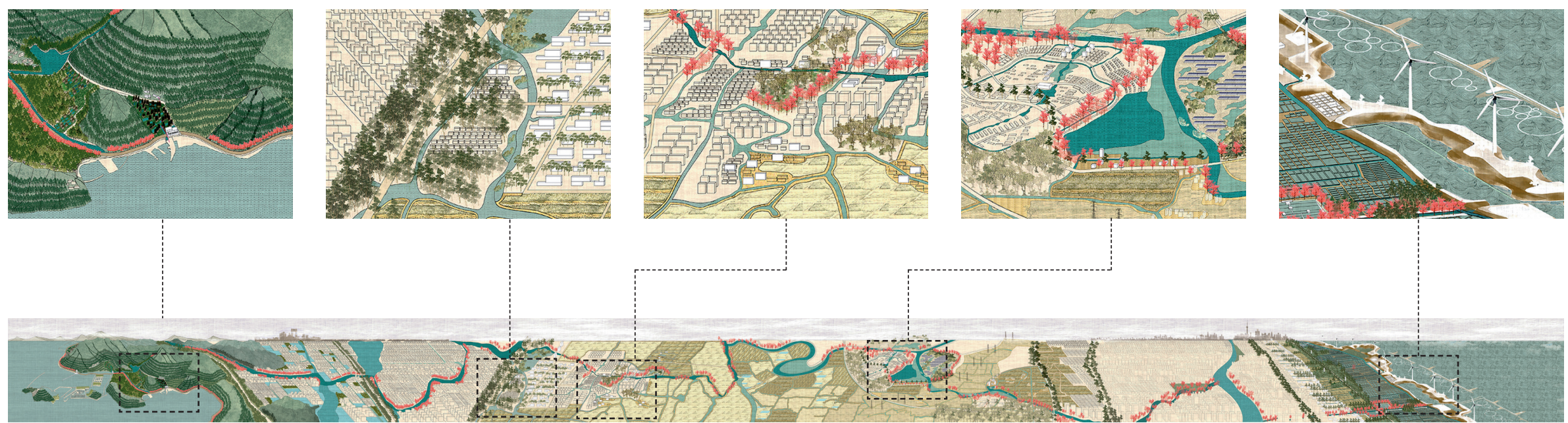
15. 自然生态修复。在三角洲 地区圢田景观进行生态修

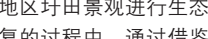
复的过程中, 通过借鉴中 国绘画技法来展现项目的 土地策略, 并对城市发 展进行了反思。

16-1. 从洪水抑制到洪水调控。 受三角洲当地传统软性洪 水调控措施的启发, 项目 构建了多尺度模型来探 水管理策略，将其作为硬 质人造抗洪设施之外的另 一质人造抗洪设施之外的男 16-2. 综合利用的零碳增长新模 式。苏州河轴线串联起高 密度、中增速、零碳等不 同的发展模式，既顺应 全球能源生产去中心化的 总体趋势, 又能满足中国 “自给自足、㓞性发展” 的目标。

15. Restoring Natural Ecologies. The techniqu of Chinese painting was used to visualize the territorial strategy of restoring natural polder landscape and polder landscape

16-1. From Flood Control to Controlled Flooding. Multi-scalar model making explored water management strategies, informed by indigenous soft measures of deltaic flood control, as an alternative for hardengineered control engineered

16-2. New Hybrid, Zero-Carbon Typologies. The spine absorbs growth in highdensity, medium-rise, zero-carbon typologies, drawing upon the global trend of decentralized Chers production with China's course towa self-resilience.
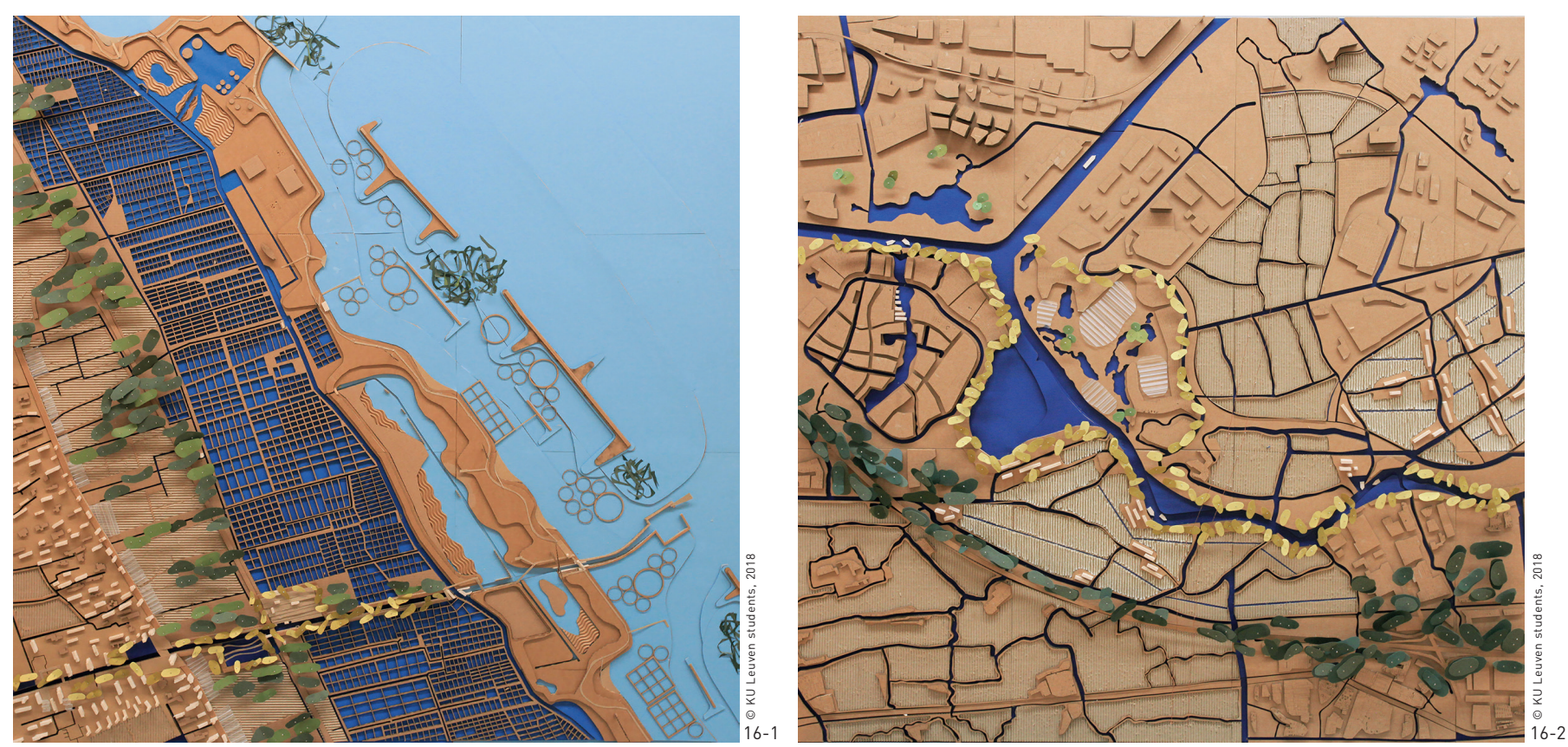

坏: 生态系统逐渐碎片化, 具有关键性作用的苏州河的上下游水网也 无法继续发挥其功用。为解决上述问题, 设计方案将苏州河重塑为贯 穿太湖流域的轴线 (图15), 并在沿线进行植树造林; 沿河创建一系 列花戋果园, 作为兼具生产、展示、休闲功能的公共景观, 以强化苏 州河生态保护线的价值; 此外, 当地原本就有在基础设施沿线种植树 木作为过滤带的做法, 设计方案建议将这一措施的实施范围扩大, 所 形成的大面积的城市林地可以固碳、缓解热岛效应, 并提供可再生生 物质能源。苏州和上海已经开始对逆城镇化与城市致密化进程加以控 制，例如在《上海市城市总体规划（2017-2035年）》中，城市居民人 口总数被限定为 2500 万。当今全球能源生产的去中心化已成为必然趋 势，中国政府也提出 “自给自足” 的发展目标，在此前提下，比起继 续建造千篇一律、空间上彼此孤立的 “飞地” ，秉持合理增速、零碳 增长理念的 “韧性轴线” 发展模式显然更符合未来的需求（图16）。 最后, 设计方案还提出了推动逆工业化与农村土地集约利用的措施, 这将有利于保证地区的生产自足和食品安全, 也迎合了中国当前的 “新农村”政策。 floods and store rainwater. Indigenous practices for deltaic flood management informed contemporary adaptation, which moves away from static flood control towards controlled flooding.

Rapid, relentless urban encroachment between Suzhou and Shanghai, super-imposed with mammoth north-south infrastructure, has significantly disturbed landscape continuity. Eco-systems are fragmented and the foundational, east-west water network of Suzhou Creek became secondary. As a response, the design requalifies Suzhou Creek as the transversal spine of the basin (Fig. 15), complemented by a territorial system of afforestation. Flowering orchard sequences strengthen the linear ecological threshold as expanded public realm embedding productive, performative, and recreational landscapes. In addition, forceful up-scaling of China's indigenous tradition of tree filters along infrastructure allows vast urban forests to perform as carbon sinks, counter the heat island effect, and provide biomass for renewable energy. In Suzhou and Shanghai, a controlled process of de-urbanisation and densification is already occurring - exemplified by the "Shanghai 2035 Masterplan" that limits the growth of the city to 25 million inhabitants. Reconciling the global decentralization trend of energy production with the Chinese dream of self-sufficiency, future growth will be absorbed along the elastic spine by medium-rise, zero-carbon typologies (Fig. 16) as an alternative for generic, vertical enclaves. Finally, as China seeks productive self-sufficiency and food security, the project embraces the national "New Countryside" policy to stimulate deindustrialization and low-density village demolition. 


\section{8 水与森林交织的比利时布鲁塞尔大都会区景观}

作者: 维姆・沃贝克 ${ }^{\odot}$

布鲁塞尔的与众不同之处是其壮丽的自然地貌：雄伟的塞内河谷 拥有广衰的洪泛平原，城市的核心地带也坐落于此; 站在海拔更高的 索尼亚森林高原上, 即可将这里的景致尽收眼底: 布鲁塞尔的城市框 架即是由 “水” 与 “森林” 这两种截然不同而又密切相关的元素所构 成。设计型研究项目 “大都会景观” 对研究区域内开放空间的潜力进 行了调查，并将开放空间嵌人到生产活动密集的城市腹地。

WIT建筑事务所与OSA将南塞内河谷作为研究区域：这里位于市 中心的上游, 土地利用形式多样, 碎片化程度较高。城市地区与其腹 地的对比也十分鲜明：在布鲁塞尔城区，水域空间被逐渐压缩，仅剩 狭窄的运河河道; 内陆的佛兰德式腹地则以自然山地 (和水体) 地貌 为主。这片地区虽然经历了人工干预, 但如今依然保留大量的开敞空 间，山地中的堤坝保障了造林和牧场用地。由于场地内的林业、农 业、休闲产业、工业，以及城市发展压力一直有增无减，因此，该项 目的设计调查探讨了将碎片化的河谷转变为 (能够引领区域未来的) 大都会景观的途径。设计方案以自然河谷肌理为框架, 使富有 21 世纪 大都会风貌的景观得以清晰呈现。

水与森林成为了本项目的生态基石。通过策略性地封堵卡塔拉的 河流颈口, 使南塞内河谷内可利用的开放空间重新成为一片广阔的洪 泛平原, 不仅创建出一种新的湿地生态, 也使高达 100 万立方米的河水 在进入城市之前得到缓冲。在水域和林地之间分布着大面积的工业用 地, 重新设计后可用来储存水资源。在这一水域与城市肌理有序交织
8 Metropolitan Landscapes of Water and Forest, Brussels, Belgium

Author: Wim Wambecq ${ }^{\circledR}$

Brussels' DNA resonates its impressive topographic setting: the monumental Senne River Valley that hosts the urban core and a large flood plain, both overseen by the higher plateau of the Sonian Forest. Water and forest, as separate yet intrinsically entangled figures, mark Brussels' urban structure. The research-by-design "Metropolitan Landscapes" investigated the potential of open space to redefine the changing and expanding urban realm into its productive hinterland.

WIT Architecten \& OSA focused on the Southern Senne Valley, a diverse and fragmented territory upstream from the city center. The contrast between the urban area and its hinterland could not be any clearer: in the Brussels urban area, space for water is reduced into narrow canals; in the Flemish hinterland, the Zennebeemden nature (and water) dominate. This component has been equally manipulated, but remained open. Dykes in the Zennebeemden, for example, reclaimed space for afforestation and grazing land. As forestry, agricultural, recreational, industrial, and urban pressures on the site only increase, the design investigation explored how the fragmented valley could become a metropolitan landscape,
(6) 作者为OSA成员, 目前 博士学位在读; 指导教 师: 布鲁诺德缪德尔。

(6) OSA on-going doctorate; promoter Bruno De Meuder.

17-1. 工业地块改造。在工业 地块上引入 $5 \sim 6$ 种联合 经营业态, 以集约利用 经营业态，以集约利用 停车场、出入口及办公 用地，节省出了一定的 造林空间。通过进行水 资源管理和微气候（热 岛效应) 调节, 这些地 块为维持河谷的良好生 态做出了贡献。

17-1. Transformation of an industrial island. Industrial islands pool five or six businesses to economize on parking, access, office spaces, etc. and to introduce an intermediate scale that allows afforestation. The islands sustain the valley ecology in terms of water management and micro-climate (heat-island effect).

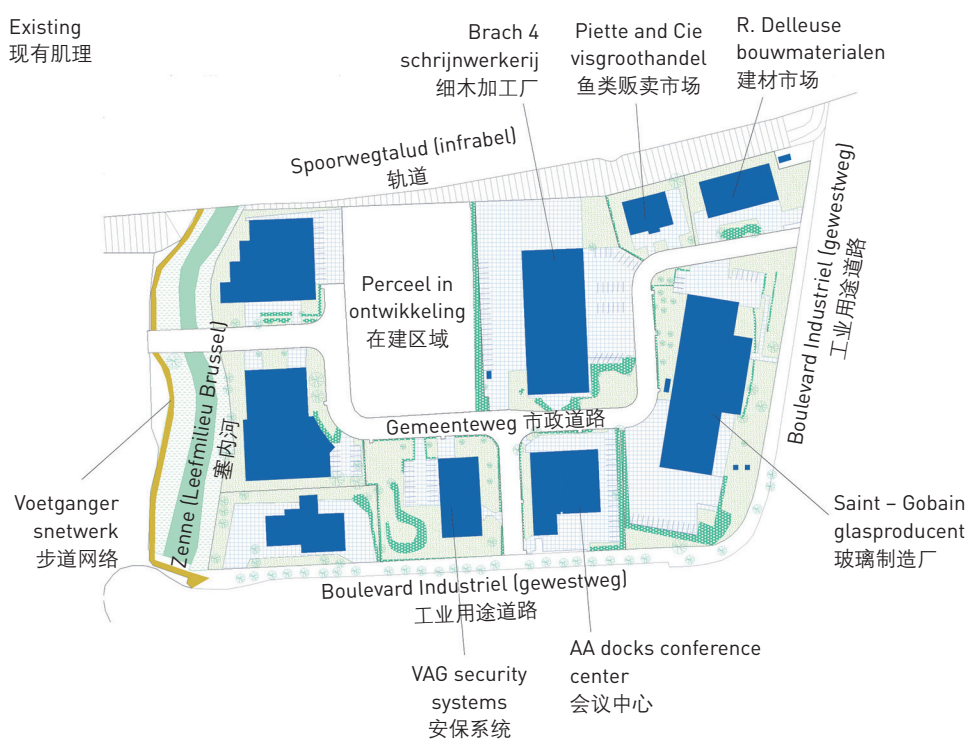

Transformation 改造方案

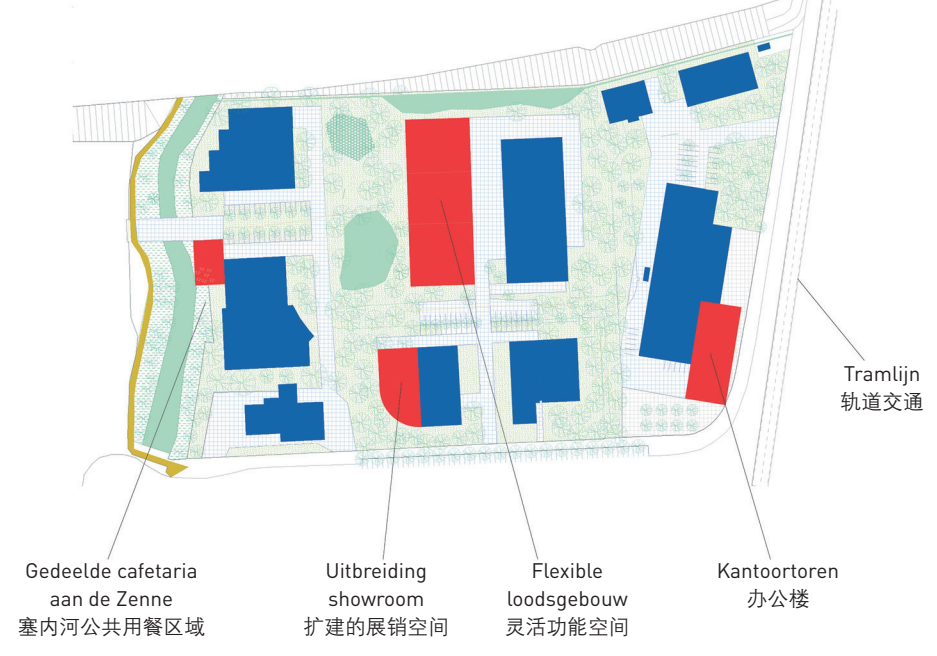



的景观序列在靠近城市 的地区学充了丰富的生 物多样性, 这将为物种 迁徙创造理想条件。在 城市中能够俯瞰洪泛平 原, 一条新建的轨道交 通观光线路联系起了高 原周边地区的林地。

17-2. Continuity of ecologies. A gradient of landscapes generates a rich biodiversity close to the city, ideal for the migration of species. The urban overlooks the floodplain. A new scenic tramway traverses the forested
的清晰构想中，一条沿河生态带得以重新建立（图17）。新形成的森 林将城市嵌人这种水域景观之中。原工业用地被恢复为林地，与滨水 空间相互交融。通过这些地块，城市在被水系环绕的同时，其生产性 功能也得以强化。整片洪泛平原上的景观框架结构由此确立。此外, 茂密的森林带沿山坡逐渐向上延伸，直至没人草木葱茏的高原，在谷 地与高山之间形成了另一条生态连续带; 有轨电车与铁路交通线从中 穿过，为林木覆盖的山坡带来鲜明的城市气息。从高原到河谷，水与 森林始终紧密地交织在一起, 构成了一系列景观画卷, 布鲁塞尔大都 会南部地区的生态也因此得以重新焕发活力。LAF

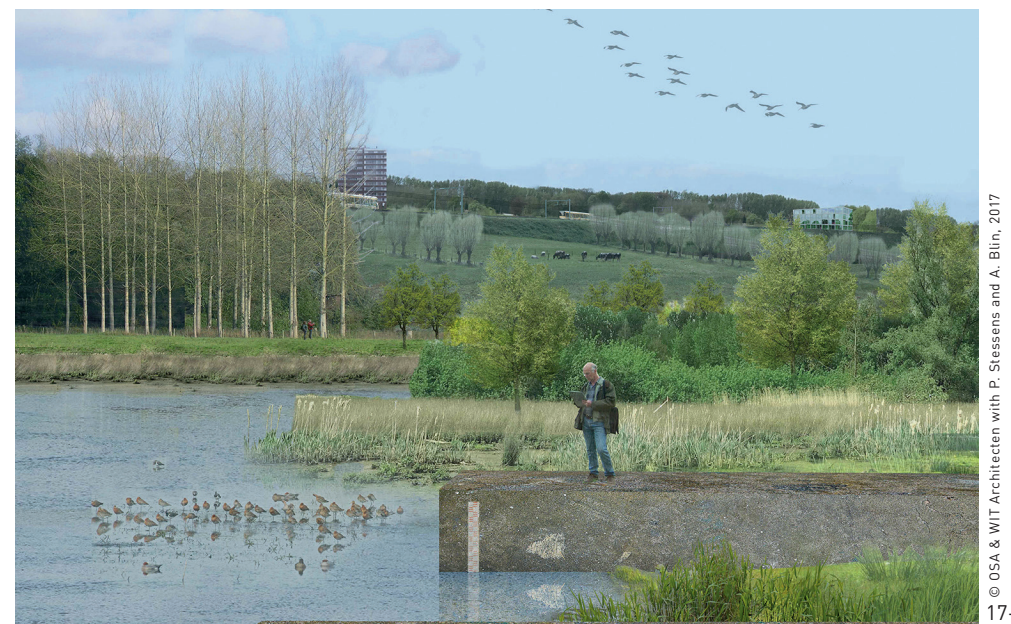

a landscape figure that could guide the future of the metropole. Consequently, the design articulates a natural valley structure that frames 21st century (metropolitan) urbanity.

Water and forest are fundamental ecological cornerstones. Available open space in the Southern Senne Valley is re-instated as a large flood plain by strategically closing the bottleneck at the Catala site. A new wet ecology can thrive while buffering up to $1,000,000 \mathrm{~m}^{3}$ of water at the entrance of the city. Inbetween, along and on large industrial plots, additional space is reimagined to store water. An explicit sequence of waterurban figures re-creates an ecological continuity along the river (Fig. 17). New forests frame the urban within this water landscape. Industrial plots are reforested, while more space for water is surrendered in-between. Within the islands, the productive city is intensified, while being embedded within the water landscape. Likewise, a structure of coulisses (landscape frames) structures the large flood plain. The mesh of thick tree lines creeps up the slope and eases into the forested plateau, creating ecological continuity from valley to plateau. The urban character of the forested slope is strengthened by the extension of tram and RER-lines. Water and forest are entangled through a range of landscape figures crossing from valley to plateau. The (south of) Brussels metropolis is retrofitted into the ecology of water and forest. LAF
[1] Shannon, K., de Meulder, B., d'Auria, V., \& Gosseye, J. (Eds.). (2008). Water Urbanisms. Amsterdam: Sun architecture.

[2] Boada Rivas, A. M. (2006). Patrones de asentamiento regiona y sistemas de agricultura intensiva en Cota y Suba, Sabana de Bogotá (Colombial. Bogotá: Fundación de Investigaciones Arqueológicas Nacionales, Banco de la República.

[3] Ortiz, M. A. D., González, J. D. N., \& López, T. S. (2005) Páramos: Hidrosistemas sensibles. Revista De Ingeniería, (22). 64-75.

[4] Ortiz, M. A. D., \& Botero, L. A. C. (2012). Valoración de cambios hidrológicos en la cuenca del río bogotá. Revista De Ingeniería, (36), 77-85.

[5] Mumford, L. (1934). Technics and Civilization. New York Harcourt, Brace \& Company.

[6] Rojas, C., de Meulder, B. \& Shannon, K. (2015). Water urbanism in Bogotá. Exploring the potentials of an interplay between settlement patterns and water management. Habita International, (48), 177-187. Retrieved from https://doi. org/10.1016/j.habitatint.2015.03.017

[7] Rojas, C. (2017). Settling with Waters. A Landscape Urbanism Investigation in the Sabana de Bogotá (Doctoral dissertation). Leuven, Belgium.

[8] Secretaria Distrital del Habitat. (2014). El déficit habitacional en Bogotá D.C. 2014: Evolución y análisis socioeconómico de los hogares. Retrieved from http://habitatencifras. habitatbogota.gov.co/documentos/Estudios_Sectoriales/El_ deficit_habitacional_en_Bogota_D_C.pdf

[9] Bebbington, A., \& Williams, M. [2008, August). Water and Mining Conflicts in Peru. Mountain Research and Development, 28(3). 190-195.

[10] Bradshaw, A. (1997, August). Restoration of mined lands - using natural processes. Ecological Engineering. 8(4) 255-269. doi: 10.1016/S0925-8574197100022-0

[11] Braudel, F. (1995). The Mediterranean and the Mediterranean world in the age of Philip II Volume I. Berkeley and Los Angeles: University of California Press.

[12] Brush, S. B. (1976, January). Man's Use of an Andean Ecosystem. Human Ecology, 422), 147-166. doi: 10.1007/ BF01531218

[13] Buytaert, W., Célleri, R., Bièvre, B. D., Cisneros, F. Wyseure, G., Deckers, J., \& Hofstede, R. (2006, November). Human impact on the hydrology of the Andean páramos. Earth-Science Reviews, 79(1-2), 53-72, doi: 10.1016/ j.earscirev.2006.06.002

[14] Murra, J. V. (2017). Reciprocity and Redistribution in Andean Civilizations: The 1969 Lewis Henry Morgan Lectures. Chicago: The University of Chicago Press.

[15] Schellie, K. L. (1977). Sand and gravel operations: a transitional land use. Silver Spring: National Sand and Gravel Association.

[16] Watanabe, S. (2001). Wariy Cajamarca. Boletín de Arqueología PUCP. (5), 531-541.

[17] Watanabe, S. (2002). El reino de Cuismancu: orígenesy transformación en el Tawantinsuyu. Boletín de Arqueología PUCP, (6), 107-136.

[18] Chan, F. K. S., Griffiths, J. A., Higgitt, D., Xu, S. Y., Zhu, F. F. Tang, Y. T, ... Thorne, C. R. (2018, July). "Sponge
City" in China-A breakthrough of planning and flood risk management in the urban context. Land Use Policy, (76), 772 778. doi: 10.1016/j.landusepol.2018.03.005

[19] Huang. Y. H. (2017) Wéi Tiàn as Water Marks of the Yangtze River Delta (Unpublished master's thesis). Katholieke Universiteit Leuven, Oude Markt 13 - bus 5005, 3000 Leuven, Belgium.

[20] Liu, G. H., Zhang, L. C., Zhang, Q., \& Musyimi, Z. M. (2015, Februaryl. The response of grain production to changes in quantity and quality of cropland in Yangtze River Delta, China. Journal of the Science of Food Agriculture, 95(3), 480-489. doi: $10.1002 /$ jsfa. 6745

[21] Ma, Z Melville, D. S., Liu, J. G., Chen, Y, Yang, H. Y., Ren, W. W. ... Li, B. (2014, November). Rethinking China's new great wall. Science, 346(6212), 912-914. doi: 10.1126/science. 1257258

[22] Nolf, C., Vannoorbeeck, F., Liu, C., \& Tang, J. (2017). Integrating Spatial Planning and Water Management in Urbanised Deltas. Unpublished manuscript. Xi'an Jiaotong Liverpool University, Suzhou, China.

[23] Shannon, K. (2013). Eco-Engineering for Water: From Soft o Hard and Back. In S. T. A. Pickett, M. L. Cadenasso \& B. McGrath (Eds) Resilience in Ecology and Urban Design: McGrath (Eds). Resilience in Ecology and Urban Design: Linking Theory and Practice for Sustainable Cities (pp. 163182). London: Springer.

24] Loeckx, A., Corijn, E., Persyn, F., Avissar, I., Smets, B., Mabilde, J., \& Vanempten, E. (2016). Metropolitan Landscapes: Open Ruimte Als Basis Voor Stedelijke Ontwikkeling; Espace Ouvert, Base De Développement Urbain Brussel : Vlaams Landmaatschappij. 